\title{
1 Revision of the Afro-Madagascan genus Costularia 2 (Schoeneae, Cyperaceae): infrageneric relationships and species delimitation
}

\author{
Isabel Larridon $^{1,2}$, Linah Rabarivola $^{3}$, Martin Xanthos ${ }^{1}$, A. Muthama Muasya ${ }^{4}$ \\ ${ }^{1}$ Identification and Naming, Royal Botanic Gardens Kew, Richmond, Surrey, United Kingdom \\ ${ }^{2}$ Department of Biology, Research Group SpermatophytesSystematics and Evolutionary Botany \\ $\underline{\text { Lab, }}$, Ghent University, Gent, Belgium \\ ${ }^{3}$ Kew Madagascar Conservation Centre, Antananarivo, Madagascar \\ ${ }^{4}$ Department of Biological Sciences, Bolus Herbarium, University of Cape Town, Rondebosch, \\ South Africa \\ Corresponding Author: \\ Isabel Larridon ${ }^{1}$ \\ Royal Botanic Gardens Kew, Richmond, Surrey, TW9 3AE, United Kingdom \\ Email address: i.larridon@kew.org
}

\begin{abstract}
A recent molecular phylogenetic study revealed four distinct evolutionary lineages in the genus Costularia s.l. (Schoeneae, Cyperaceae, Poales). Two lineages are part of the Oreobolus clade of tribe Schoeneae: the first being a much-reduced genus Costularia s.s., and the second a lineage endemic to New Caledonia for which a new genus Chamaedendron was erected. The other two lineages were shown to be part of the Tricostularia clade of tribe Schoeneae. Based on morphological and molecular data, the genus Costularia is here redelimited to represent a monophyletic entity including 15 species, which is restricted in distribution to southeastern Africa (Malawi, Mozambique, South Africa, Swaziland, Zimbabwe), Madagascar, the Mascarenes (La Réunion, Mauritius), and the Seychelles (Mahé). Molecular phylogenetic data based on two nuclear markers (ETS, ITS) and a chloroplast marker $(\operatorname{trn} L-F)$ resolve the studied taxa as monophyletic where multiple accessions could be included (except for $C$. laxa and $C$. purpurea, which are now considered conspecific), and indicate that the genus dispersed once to Africa, twice to the Mascarenes, and once to the Seychelles. Two endemic species from Madagascar are here described and illustrated as new to science, as is one additional species endemic to La Réunion. Two taxa previously accepted as varieties of $C$. pantopoda are here recognised at species level $(C$. baronii and $C$. robusta). We provide a taxonomic revision including an identification key, species descriptions and illustrations, distribution maps, and assessments of conservation status for all species.
\end{abstract}




\section{Introduction}

The genus Costularia C.B.Clarke (Cyperaceae tribe Schoeneae) was previously circumscribed as including 25 species (Govaerts et al., 2018). However, a recent molecular phylogenetic study firmly established the polyphyly of the genus as previously circumscribed (Larridon et al., 2018a), which was already hinted at in previous works (Seberg, 1986, 1988a, b; Browning \& Gordon-Gray, 1995; Bruhl, 1995; Zhang et al., 2004; Verboom, 2006; Viljoen et al., 2013) and supported in the most recent family-wide study (Semmouri et al., 2018). Larridon et al. (2018a) showed that Costularia s.l. included four distinct lineages: (1) Costularia s.s. (11 spp.) from Africa, Madagascar, the Mascarenes and Seychelles, (2) Chamaedendron Larridon (5 spp.) from New Caledonia, (3) a group largely conforming to Costularia subgenus Lophoschoenus sensu Kükenthal (1939) (8 spp.) from New Caledonia and Malesia that is now considered to be part of a redelimited genus Tetraria, nom. cons. prop. (Larridon et al., 2017a, 2018a, $b$ ), and (4) the species Xyroschoenus hornei (C.B.Clarke) Larridon (basionym: Schoenus hornei C.B.Clarke, nom. cons. prop.; Larridon et al., 2017b, 2018a) which is endemic to the Seychelles. Only the latter species and species of Costularia s.s. are found in Africa and/or on the islands in the Indian Ocean (Henriette et al., 2015; Larridon et al., 2018a). Three earlier publications revised species of Costularia s.s. (Chermezon, 1937; Kükenthal, 1939; Henriette et al., 2015) since Clarke (1898) erected the genus based on the species Costularia natalensis C.B.Clarke, as well as a species now included in Capeobolus Browning (Costularia brevicaulis C.B.Clarke; Browning \& Gordon-Gray, 1999). Table 1 gives an overview of the seven species of Costularia s.s. treated by Chermezon (1937), the nine species treated by Kükenthal (1939), and the 11 currently recognised species (Govaerts et al., 2018). Costularia s.s. as here accepted more or less equates to Costularia subgenus Costularia sensu Kükenthal (1939) (Larridon et al., 2018a). The Catalogue of the Vascular Plants of Madagascar states that there may still be a number of new Madagascan endemic species to describe (Tropicos.org, 2018). This study is part of a wider effort to revise genera of Cyperaceae from Africa and Madagascar (Bauters et al., 2018, accepted; Galán Díaz et al., redelimited-as a monophyletic entity, (2) test the relationships between the species and investigate species limits where possible are investigated-based on molecular sequenced data, and (3) place previously overlooked species are placed in a phylogenetic context and formally describe themd. A taxonomic treatment including an identification key to all species, species descriptions and illustrations, distribution maps, and assessments of conservation status are provided.

\section{Materials \& Methods}

\section{Ethics statement}

Parts of Tthe specimens studied were collected as a part ofduring field expeditions before the 2010 AETFAT conference held in Antananarivo, Madagascar funded by a grant from the Research Foundation - Flanders (FWO) (K204910N), and with support of the Department of 
Biology, Ghent University, Belgium. Permits to collect and export these specimens were issued by the Madagascar authorities: a collecting permit for Cyperaceae in Madagascar ( ${ }^{\circ} 082 / 10 / \mathrm{MEF} / \mathrm{SG} / \mathrm{DGF} / \mathrm{DCB} . \mathrm{SAP} / \mathrm{SLRSE}$ - Isabel Larridon) was provided by ANGAP Madagascar National Parks authority. The other specimens studied are available in publicly accessible herbaria (BR, G, GENT, K, L, MAU, P, REU, TAN and UPOS; Thiers, continuously updated).

\title{
Nomenclature and Ttaxonomy
}

A nomenclatural study including the taxonomic history of the genus and its species, critical for the correct coining of the new names and the proper use of prior ones, was performed. The electronic version of this article in Portable Document Format (PDF) will represent a published work according to the International Code of Nomenclature for algae, fungi, and plants (ICN), and hence the new names contained in the electronic version are effectively published under that Code from the electronic edition alone. In addition, new names contained in this work which have been issued with identifiers by IPNI will eventually be made available to the Global Names Index. The IPNI LSIDs can be resolved and the associated information viewed through any standard web browser by appending the LSID contained in this publication to the prefix "http://ipni.org/". The online version of this work is archived and available from the following digital repositories: PeerJ, PubMed Central, and CLOCKSS.

\begin{abstract}
Molecular study
All known Costularia s.s. species, except C. microcarpa (Cherm.) Kük. which is only known from its type and $C$. brevifolia Cherm. which is rare in collections, were sampled (representing c. $\underline{80 \% \text { of the diversity of the genus, i.e. } 9 \text { out of } 11 \text { species and } 2 \text { out of } 3 \text { heterotypic varieties }}$ recognised by Govaerts et al., 2018) using multiple accessions per taxon where possible. Additionally, samples were included from several taxa potentially representing new species. The outgroup taxa, selected based on Larridon et al. (2018a), consist of nine species representing the other four genera of the Oreobolus clade of tribe Schoeneae. A total of 36 samples (15 newly sequenced) from 24 different taxa were used for this study. The samples with species names, voucher information, origin and GenBank accession numbers for the sequences, are given in Supplemental Information File Table S1. The DNA extraction protocol, markers (ETS, ITS and $\operatorname{trn} L-F)$, and material and methods for PCR amplification and sequencing and for obtaining alignments follow Larridon et al. (2018a). Sequences were assembled and edited in Geneious R8 (http://www.geneious.com, Kearse et al., 2012), aligned using MAFFT 7 (Katoh et al., 2009; Katoh \& Standley, 2013) with 'maxiterate' and 'tree rebuilding number' set to 100 (long run), afterwards, alignments were checked manually in PhyDE 0.9971 (Müller et al., 2010). The alignments used to produce the phylogenies are available as a Supplemental Information File Data $\mathrm{S} z \underline{1}$.

We first inferred the gene trees for each of the three regions separately to identify potential incongruence. As there were no instances of conflict at well-supported nodes
\end{abstract}


(Supplemental Information Files Figs. S31-S68), the matrices of the three regions were concatenated for the downstream analyses. PartitionFinder 2.1.1 (Lanfear et al., 2012) was used to determine an appropriate data-partitioning scheme from potential partitions that were defined a priori (in this case, each marker was treated as a separate partition), as well as the best-fitting model of molecular evolution for each partition, using the Bayesian Information Criterion.

PartitionFinder confirmed the a priori data-partitioning scheme, and the GTR $+\mathrm{I}+\Gamma$ (invgamma) model of sequence evolution was determined to be the best-fitting model for the two nrDNA markers, while the GTR $+\Gamma$ (gamma) model of sequence evolution was determined to be the bestfitting model for the $\operatorname{trn} L-F$ partition in the concatenated data set.

Maximum likelihood (ML) analyses of the optimally partitioned data were performed using RAxML 8.2.10 (Stamatakis, 2014). The search for an optimal ML tree was combined with a rapid bootstrap analysis of 1000 replicates. Additionally, Ppartitioned analyses were conducted using Bayesian Inference (BI) in MrBayes 3.2.6 (Ronquist et al., 2012). Rate heterogeneity, base frequencies, and substitution rates across partitions were unlinked. The analysis was allowed to run for 100 million generations across four independent runs with four chains each, sampling every 10,000 generations. Convergence, associated likelihood values, effective sample size (ESS) values and burn-in values of the different runs were verified with Tracer 1.5 (Rambaut \& Drummond, 2007). The first $25 \%$ of the trees from all runs were excluded as burn-in before making a majority-rule consensus of the 30,000 posterior distribution trees using the "sumt" function. All phylogenetic analyses were run using the CIPRES portal (http://www.phylo.org/; Miller et al., 2011), and were executed for both full and reduced sampling alignments. Trees were drawn using TreeGraph2 (Stöver \& Müller, 2010).

\section{Morphological study}

Herbarium specimens of BR, G, GENT, K, L, MAU, P, REU, TAN and UPOS (Thiers, continuously updated) were studied morphologically using a Leica (Leica Microsystems, Wetzlar, Germany) binocular microscope. Measurements where made with a ruler (e.g. leaf and culm length), or using a binocular microscope with graticule (e.g. spikelet and glume length). When measuring width, this was done near the middle of the organ (e.g. middle of the culm). The term peducles represents the main inflorescence branches measured from base of primary inflorescence bract to second order bract. Where possible, links to imaged type specimens are provided (Catalogue des herbiers de Genève, 2018; HerbCat, 2018; Muséum national d'Histoire naturelle, 2018)

\section{Species distributions and conservation assessments}

Information on locality data was obtained from the studied herbarium records (see Taxonomic Treatment and Supplemental Information File Data S2 3 ). Georeferenced localities were used to map the distribution of the Costularia species studied in SimpleMappr (Shorthouse \& David, 2010). The extent of occurrence (EOO) and area or occupancy (AOO) of the species were calculated in GeoCAT (Bachman et al., 2011), where the AOO was based on a user defined cell 
width of $2 \mathrm{~km}$ in line with IUCN Red List criteria (IUCN, 2012). Conservation assessments were prepared according to the guidelines to the IUCN Red List categories and criteria (IUCN, 2012; IUCN Standards and Petitions Subcommittee, 2014).

\section{Results}

\section{Molecular study}

The multiple-locus BI topology (Fig. 1) did not differ from the multiple-locus ML tree (Supplemental Information File Fig. S구), except for the sister relationship of clade B. Clade B is sister to clade A in multiple-locus BI topology (Fig. 1), but sister to clade $\mathrm{C}$ in the multi-locus ML-analysis (Supplemental Information File Fig. S97). This relationship is not supported in either result. Four subclades are well supported in the phylogenetic hypothesis (Fig. 1) of the Oreobolus clade of tribe Schoeneae: Costularia (BI posterior probability value 1, ML bootstrap value 100), Chamaedendron (1, 100), Capeobolus + Cyathocoma Nees $(1,100)$, and Oreobolus R.Br. (0.81). In Costularia, four main clades are well supported: clade A (1, 100), and clade B $(1,100)$, clade C $(1,100)$ and clade D $(1,98)$. In clade A, two species C. leucocarpa (Ridl.) H.Pfeiff. $+C$. andringitrensis (formally described in the Taxonomic Treatment) form a supported clade (88) in which C. leucocarpa is well supported as a monophyletic lineage (1, $100)$. These two species are sister to a monophyletic Costularia natalensis $(1,99)$. In turn, Costularia itremoensis (formally described in the Taxonomic Treatment) is sister to these three species. Clade B consists of the C. pantopoda (Baker) C.B.Clarke ex Cherm. species complex with each of the taxa: C. baronii C.B.Clarke $(1,95)$ and $C$. robusta $(0.99,80)$ (formally recognised at species level in the Taxonomic Treatment) forming well supported monophyletic lineages separate from the typical $C$. pantopoda (Fig. 1). In all analyses, the $C$. baronii and $C$. robusta appear more closely related to each other thaen to C. pantopoda s.s. (Fig. 1; Supplemental Information Files Figs. S13-S97). A last taxon part of this clade, sister to the rest, is a taxon currently identified as Costularia cf. pantopoda. Clade $\mathrm{C}$ contains two well supported subclades, one of which $(1,98)$ includes specimens identified as $C$. laxa Cherm. and as $C$. purpurea Cherm. The latter taxa are supported as monophyletic in some but not all analyses. The second well supported subclade $(1,100)$ consists of individuals of $C$. melicoides (Poir.) C.B.Clarke. Clade D includes four species: a well supported C. xipholepis (Baker) Henriette \& Senterre $(1,100)$, a single accession of $C$. melleri (Baker) C.B.Clarke ex Cherm., and a well supported subclade $(1,90)$ including $C$. cadetii (formally described in the Taxonomic Treatment) and C. humbertii Bosser.

\section{Morphological study, species distributions and conservation assessments}

Morphological results, species distributions and conservation assessments are elaborated in the Taxomic Treatment. The additional herbarium specimens studied per taxon are listed in Supplemental Information File Data S32.

\section{Discussion}


Four clades are here retrieved in the Oreobolus clade of tribe Schoeneae (Fig. 1): Costularia, Chamaedendron, Capeobolus + Cyathocoma, and Oreobolus, in line with recent studies (Larridon et al., 2018a; Semmouri et al., 2018). Viljoen et al. (2013) reconstructed the ancestral areas for tribe Schoeneae but did not obtain a clear result for the ancestral area of the Oreobolus clade. Both Capeobolus and Cyathocoma are found in the Cape Floristic Region, while Chamaedendron is endemic to New Caledonia, and Oreobolus has a wider distribution in the souther hemisphere (Malesia to Australasia, Hawaiian Islands, Costa Rica to Falkland Islands; Govaerts et al., 2018).

Of the four main clades in Costularia, only clade B is restricted to Madagascar, while the others include Madagascar endemics and species found on the Indian Ocean islands and/or mainland Africa (Fig. 1). In clade A, the Madagascan endemic species C. leucocarpa and $C$. andringitrensis are sister to $C$. natalensis from southeastern Africa. Costularia itremoensis from South Central Madagascar is sister to these three species (Fig. 1). Clade B consists of the $C$. pantopoda species complex with $C$. baronii and C. robusta forming well supported monophyletic lineages separate from the typical $C$. pantopoda (Fig. 1). Costularia robusta was first described as Costularia baronii var. robusta Cherm. This concurs with our results in which C. baronii and C. robusta are sister species (Fig. 1). A last taxon part of this clade, sister to the others, is currently identified as Costularia cf. pantopoda. This taxon needs further study since it is only known from a single collection with little metadata information. Its morphology appears intermediate between $C$. pantopoda and $C$. itremoensis. Potentially related to clade B is $C$. microcarpa, a species first described by Chermezon (1937) under C. baronii (as C. baronii C.B.Clarke var. microcarpa Cherm.), and later raised to species level by Kükenthal (1939). Clade C contains two well supported subclades, one of which includes specimens identified as $C$. laxa and $C$. purpurea. These taxa were not always recovered as monophyletic (Supplemental Information Files Figs. S 13 -S $8 \underline{6}$ ). Morphological study confirmed that the delimitation between these taxa is unclear, resulting in the decision to combine the two species under a single species name: $C$. purpurea (see Taxonomic Treatment). The second well supported subclade of Clade $\mathrm{C}$ consists of individuals of C. melicoides (Fig. 1). Costularia melicoides is endemic to the Mascarenes where it is found on both the islands of La Réunion and Mauritius. Clade D includes four species: C. xipholepis, a recently rediscovered species endemic to the Seychelles (Henriette et al., 2015), a single accession of $C$. melleri from Central Madagascar, and a subclade including $C$. cadetii and $C$. humbertii. The newly discovered $C$. cadetii and the species $C$. humbertii stand out due to their smaller stature and shorter leaves. Both are restricted to high-elevation zones, but what is remarkable is that while C. humbertii is found in the northeast of Madagascar (Marojejy National Park), C. cadetii is endemic to La Réunion where it is limited to peaks of the island's volcanoes. This sister relationship points at a long-distance dispersal event likely from the mountain tops of northeastern Madagascar to those of La Réunion. A species potentially related to $C$. humbertii is $C$. brevifolia with which it shares characters such as a robust caudex, short stature, and short broad leaves, although it is biogeographically (southeastern Madagascar) and ecologically (low-mid elevation) isolated from it (Fig. 2). 
Of the 15 species of Costularia recognised here, three-quarters are threatened with extinction because of their restricted distribution ranges and human impact (see Taxonomic Treatment). In Madagascar, habitat destruction and deterioration are the major threats. Additional threats may relate to climate change as some species exclusively occur at (very) high elevation (e.g. C. cadetii, C. humbertii, C. robusta), or to invasive species (e.g. in the Mascarenes). Two species were assessed as Critically Endangered (CR), six as Endangered (EN) and three as Vulnerable (VU) according to IUCN Red List categories and criteria (IUCN, 2012; IUCN Standards and Petitions Subcommittee, 2014). Two endemic but widely distributed species from Madagascar (C. leucocarpa, C. purpurea) were assessed as Least Concern (LC), as was $C$. natalensis, the only species occurring in mainland Africa. A final species (C. microcarpa) could not be assessed at this time due to lack of information and is considered Data Deficient (DD). Further research and fieldwork are needed to study the species of Costularia, their populations and the threats they face.

\section{Taxonomic treatment}

Costularia C.B.Clarke in W.H.Harvey \& auct. suc. (eds.), Fl. Cap. 7: 274. 1898.

Type: Costularia natalensis C.B.Clarke (lectotype designated by Goetghebeur, 1986).

Perennial herbs, small to tall, tufted or more rarely shortly rhizomatous, caudex sometimes present. Culms scapose or with few nodes. Leaves usually both basal and caudal; basal leaves with poorly defined sheaths; cauline leaves enveloping up to $1 \frac{1}{2}$ internode length; margins scabrid, spirodistichous, eligulate, blade sometimes deciduous. Inflorescence terminal, (contracted) paniculate with few to numerous spikelets; primary bracts \pm leaf-like, sheathing. Spikelets with several distichous, deciduous glumes, of increasing length, the upper (1-)2 glumes each subtending a flower, enclosed by the wings of the next glume. Flowers, lower one (functionally) male (rarely bisexual or absent), upper one bisexual or functionally female (rarely functionally male). Perianth bristles 6 , fimbriate to ciliate, mostly longer than the nutlet and deciduous with it. Stamens 3. Style trifid, style base often distinct (at anthesis), thickened, persistent, often scabrid. Nutlet ovoid or oblong, rounded trigonous, often 3-ribbed, \pm stipitate, beaked, surface smooth or rugulose.

Includes: 15 species.

Distribution: southeastern Africa (Malawi, Mozambique, South Africa, Swaziland, Zimbabwe), Madagascar, the Mascarenes (La Réunion, Mauritius), and the Seychelles (Mahé).

\section{Key to the species of Costularia}

1 Small p plants <30 cm tall with flowering culm scarcely exceeding the basal leaves; cauline leaves absent. 
2 Inflorescence a contracted panicle, composed of few to several spikelets; s Spikelets with lower flower male, upper flower bisexual (endemic to Andringitra Mountains, Madagascar).

2 Inflorescence a some what contracted panicle, composed of numerous spikelets; s Spikelets with two bisexual flowers (endemic to La Réunion).

4. C. cadetii long, apex rounded-obtuse. 3 Basal leaves not conspicuously short compared to the flowering culm; with leaf blades longer $\geq$ $\underline{15 \mathrm{~cm}}$, apex generally long tapering.

4 Caudex 4-5 cm wide; basal leaves spirodistichous; leaf blades 7-12 mm wide; pedicels of the spikelets 5-20 mm long (endemic to SE Madagascar). 3. C. brevifolia 4 Caudex 1-2 cm wide; basal leaves distichously and flabellately inserted on the caudex; leaf blades 5-8 mm wide, sickle-shaped; pedicels of the spikelets 1-4 mm long. (endemic to NE Madagascar). 5. C. humbertii 5 Spikelets up to $3.8-5 \mathrm{~mm}$ long. 7. C. leucocarpa 5 Spikelets $>5.5 \mathrm{~mm}$ long. ...6 6 Flowers, 2, lower bisexual, upper male (or rarely only 1 flower) (Madagascar, Mascarenes).7 6 Flowers 2, lower male, upper bisexual (Africa, Madagascar, Seychelles). 7 Pedicels of the spikelet erect; glumes reddish-black, with colourless-whitish margins; nutlet smooth (La Réunion, Mauritius). 8. C. melicoides 7 Pedicels of the spikelet generally curved; glumes entirely (dark) purple; nutlet rugulosereticulate (Madagascar). 13. C. purpurea 8 Glumes 16-18 per spikelet. 9. C. melleri 8 Glumes 5-14 per spikelet. 9 Culm $<1 \mathrm{~mm}$ wide; leaf blades $\leq 1.5 \mathrm{~mm}$ wide. ..12b. C. pantopoda var. gracilenscens 9 Culm $\geq 1.5 \mathrm{~mm}$ wide; leaf blades wider than $1.5 \mathrm{~mm}$. 10 Very robust and tall perennial herbs with eCulms c. $6 \mathrm{~mm}$ wide. . .10 10 Plants less robust with cuums $\leq \underline{1.5-5} \mathrm{~mm}$ wide. . .11 11 Caudex not present; glumes 8-12 per spikelet, straw-coloured to purplish striate (endemic to SE Madagascar). 10. C. microcarpa 11 Caudex strongly developed and long; glumes 12-14 per spikelet, purplish black (endemic to N Madagascar). 14. C. robusta 12 Aedium sized to tall perennial herb; $\forall$ Vegetative culm $17-70 \mathrm{~cm} \times 1.7-3.5 \mathrm{~mm}$; cauline leaves $1-2$. 13 12 Plants generally taller and more robust; $\vee$ Vegetative culm $50-150 \mathrm{~cm} \times 2.5-5 \mathrm{~mm}$; cauline leaves $2-5$. . .14 13 Peduncles (main inflorescence branches measured from base of primary inflorescence bract to second order bract) longest 5.5-11 cm; empty glumes 6-11...... 6. C. itremoensis 13 Peduncles longest 4-5 cm; empty glumes 3-6. .12a. C. pantopoda var. pantopoda

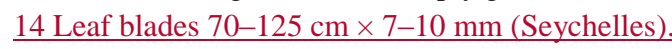
15. C. xipholepis
Kommentiert [IL1]: Information moved to the Material and Methods sections with the other info about measurements. 

16 Peduncles long (longest up to c. $15 \mathrm{~cm}$ ); spikelets oblong; glumes largest 6-7 mm long (SE Africa). 11. C. natalensis

16 Peduncles short (longest c. 5-8 cm); spikelets lanceolate; glumes largest 5.5-6 mm long (endemic to Madagascar).

2. C. baronii

\section{Costularia andringitrensis Larridon sp. nov.-Figs. 2-4}

Type. Madagascar, Fianarantsoa, Haute Matsiatra, Andringitra National Park, Diavolana Trail, 2207'28.0"S, 4652'32.7"E, 2063 m, 18 April 2010, I. Larridon, W. Huygh, M. Reynders, A.M. Muasya \& V.ena Randrianasolo 2010-0140 (holotype TAN!, isotypes BOL!, GENT!).

Diagnosis: Costularia andringitrensis differs from all other Costularia species from Madagascar by its small stature with the flowering culm scarcely exceeding the leaves. In this aspect it mostly resembles Costularia cadetii from La Réunion from which it can easily be distinguished by the latter maturing two nutlets per spikelet.

Small perennial herb, flowering culm up to $24 \mathrm{~cm}$, scarcely exceeding the leaves. Caudex absent. Culm (excluding the inflorescence) short and slender, 5-7.2 cm $\times 1.1-1.2 \mathrm{~mm}$. Basal leaves distichous, bases of old burnt leaves can be present; leaf sheaths $1.5-2 \mathrm{~cm} \times$ up to $4 \mathrm{~mm}$, only slightly wider than the leaf blade, indistinct, straw-coloured to green; leaf blades linear, flat, 8-34 cm × 1.2-2.6 mm, margins scabrid. Cauline leaves absent. Inflorescence a contracted panicle, $12-19 \times 0.5 \mathrm{~cm}$, composed of few to several spikelets; inflorescence bracts 6 , unequal, sheathing, dark reddish brown, margins scabrid; longest bract $12.5-15 \mathrm{~cm} \times 2.5 \mathrm{~mm}$. Peduncles unequal, up to $2.6 \mathrm{~cm}$ long, margins smooth to scabrid. Pedicels of the spikelets unequal, 1-5 $\mathrm{mm}$ long, minutely papilose, margins scabrid. Spikelets lanceolate, (4-)5-5.5 × 1.1-2 mm, dark purple. Glumes distichous, narrowly ovate, boatshaped, acuminate (upper glumes) to long mucronate (up to c. $1 \mathrm{~mm}$, lower glumes), 3-4 × 1.5-2 mm, dark purple on upper part including mucro if present and pale brown on lower part, margins scabrid; 3 lower glumes empty, 2 upper glumes fertile. Flowers 2, lower male, upper bisexual. Perianth bristles 6, pale, thin, antrorsely ciliate, up to $13 \mathrm{~mm}$ long. Stamens 3. Style deeply trifid. Immature nutlet (see Fig. 3D) rounded trigonous with distinct bulbous style base remaining; ripe nutlets not studied as they were already shed from plants in all available specimens.

\section{Distribution}

The species is only known from south-central Madagascar, where it was found in the Andringitra National Park, Haute Matsiatra region, Fianarantsoa province (Fig. 2).

\section{Ecology}


This species is found in near rocks in grassland to ericoid shrubland vegetation at 2000-2500 m in elevation.

\section{Phenology}

Immature inflorescence observed in November, while the specimen collected in April had already shed its ripe nutlets.

\section{Etymology}

The species is named for the Andringitra National Park in Madagascar.

\section{Conservation status}

Costularia andringitrensis is a small perennial herb endemic to Madagascar, where it is only known from two specimens and occurs in a restricted area in the Andringitra National Park. It is only known from a single location and a minimum AOO of $8 \mathrm{~km}^{2}$. However, there are other potential areas of occurrence for the species that have not yet been explored. The species is threatened by cattle grazing and by fires started for pastoral reasons which can easily get out of control and enter the National Park (I. Larridon, pers. obs. 2010; F. Rakotonasolo, pers. obs. 2017). Therefore, it is assessed as Critically Endangered: CR B2ab(ii,iii).

\section{Notes}

As is commonly seen in tropical with high elevation Cyperaceae species occurring at high elevation (I. Larridon, pers. obs.), Costularia andringitrensis is characterised by very dark spikelets. In the molecular phylogenetic hypothesis (Fig. 1), it is retrieved as sister to $C$. leucocarpa.

Although species of tribe Schoeneae are adapted to natural fire, if fire frequency is increased, especially by herders, this can threaten their regeneration (A.M. Muasya, personal observations). However, complete absence of fire can also be a threat as most species occur in habitats where open/forest are alternative states. Forests are kept out by the fire, whose absence could lead to forest encroachment. Most species of tribe Schoeneae are shade intolerant and thus would die if shaded.

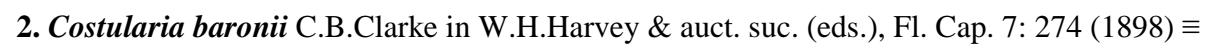
Costularia pantopoda var. baronii (C.B.Clarke) Kük., Repert. Spec. Nov. Regni Veg. 41: 67 (1939)-Figs. 5, 6

Type (lectotype designated here). Madagascar, Central Madagascar, R. Baron 3316 (holotypelectotype: K000244885!, isolectotype: MNHN-P-P00459989!).

Robust perennial herb. Culms $20-80 \mathrm{~cm} \times$ c. $5 \mathrm{~mm}$, generally quite robust. Basal leaves with leaf blades $40-80 \mathrm{~cm} \times 2-6 \mathrm{~mm}$ wide, flat. Cauline leaves 2 . Inflorescence a narrow, tight, very upright panicle with numerous spikelets; inflorescence bracts $8-11$. Peduncles erect, the longest 5-8 cm. Pedicels of the spikelets erect, 1-5 mm long. Spikelets lanceolate, 6-8 8 1.5-2 
mm. Glumes 8-12, reddish brown to black, lanceolate, subobtuse, stronglye distichous, the largest 5.5-6 mm long, lower 6-10 empty; empty glumes much smaller than the fertile glumes. Nutlet subglobose, weakly trigonous, $2.25 \mathrm{~mm}$ long, rugolose, greyish green; beak $0.75 \mathrm{~mm}$ long, obtuse, not depressed at the base, almost as wide as the nutlet.

\section{Distribution}

Costularia baronii occurs in the Antananarivo, Fianarantsoa and Toliara provinces of Madagascar (Fig. 5).

\section{Ecology}

It has been found growing in rocky areas (e.g. rock crevices along a stream bank), ericoid shrubland at elevations of 1300 to almost $2200 \mathrm{~m}$.

\section{Phenology}

Flowering specimens were collected in March to May, fruiting plants in October, while plants collected in December and January had either shed their nutlets or bore very young inflorescences.

\section{Conservation status}

Costularia baronii is distributed in the Antananarivo, Fianarantsoa and Toliara provinces of Madagascar, and occurs in at least four protected areas, i.e. Andringitra, Ankaratra Massif, Andohahela, Ibity Massif and Pic d'Ivohibe. Threats to this taxon need further investigation but in the Andrigitra National Park, its habitat and area of occupancy are impacted negatively by cattle grazing and by fires started for pastoral reasons which can easily get out of control and enter the National Park (I. Larridon, pers. obs. 2010; F. Rakotonasolo, pers. obs. 2017). Based on ten georeferenced herbarium specimens, the species occurs in at least seven locations and has an estimated AOO of $36 \mathrm{~km}^{2}$ and an EOO of $16292 \mathrm{~km}^{2}$. Using IUCN criteria, it can be assessed as VU B1ab(ii,iii)+2ab(ii,iii).

\section{Notes}

Chermezon (1937) identified Humbert 7008 as Costularia pantopoda var. pantopoda. However, we believe this specimen better fits with the description of $C$. baronii.

3. Costularia brevifolia Cherm., Bull. Soc. Bot. France 69: 723. 1922 publ. 1923. $\equiv$ Tetraria brevifolia (Cherm.) T.Koyama, J. Fac. Sci. Univ. Tokyo, Sect. 3, Bot. 8: 74. 1961-Figs. 2, 7 Type (lectotype designated here). Madagascar, Toliara, Mananara Bassin, 700 m, June 1919, H. Perrier de la Bâthie 12643 (hølelectotype: MNHN-P-P00459974!; isolectotypes: MNHN-P-P00459972!, MNHN-P-P00459973!). 
Robust perennial herb. Caudex $10-12 \mathrm{~cm} \times 4-5 \mathrm{~cm}$. Culm (appearing) lateral, robust, 50-80 cm $\times 5-8 \mathrm{~mm}$, smooth, with obtuse edges, slightly compressed. Basal leaves spirodistichously inserted on the caudex, leaf sheaths, 3-4 cm $\times 3-4 \mathrm{~cm}$, brown, shiny, margins scarious, at the apex abruptly contracted, old sheaths fibrous, leaf blades $7-10 \mathrm{~cm} \times 7-12 \mathrm{~mm}$, flat, leathery, margins scabrid, revolute, apex rounded-obtuse. Cauline leaves 1-3, far apart, sheathing, sheaths brown. Inflorescence a panicle c. $45 \mathrm{~cm}$ long, loosely compound. Peduncles unequal, up to 7.5 $\mathrm{cm}$ long. Pedicels of the spikelets suberect or curved, 5-20 mm long. Spikelets oblonglanceolate, compressed, apex subacute, 7-8 $\mathrm{mm} \times 1.5-2 \mathrm{~mm}$. Glumes distichous, oblonglanceolate, 5-6 mm long, densely imbricate, straw-coloured to brown, purple-tinged, edges only from the keel up sparsely ciliolate, prominently acute or mucronate, lower 3-4 glumes empty, 2 upper glumes fertile. Flowers 2, lower male, upper bisexual. Perianth bristles 6, pale brown, plumose, three times longer than the nutlet. Stamens 3, filaments reddish-brown, anthers linear, connective conical-subulate, purple. Style long, deeply trifid, pale, with a triangular thickly coneshaped persistant base. Nutlet $1.5 \mathrm{~mm}$ long, brown, obovate-oblong, with an attenuate base.

\section{Distribution}

Endemic to southeastern Madagascar and only known from the Atsimo Atsinana and Anosy regions in the Fianarantsoa and Toliara provinces (Fig. 2).

\section{Ecology}

It has been found growing on humid rocks in peatlands, on laterite and granite in tropical forest, and in faults of gneiss rock escarpments, at elevations of (200-)600-900 m.

\section{Phenology}

Flowering specimens were collected from in March. Young inflorescences can be observed on the specimens collected in February, while old inflorescences remain on the plants until October-November.

\section{Conservation status}

Costularia brevifolia is a robust perennial herb, limited in distribution to the forested mountain ranges of south-eastern Madagascar at mid-elevation. It is known from only four locations. The estimated extent of occurrence (EOO) is $2463 \mathrm{~km}^{2}$ and the area of occupancy is $20 \mathrm{~km}^{2}$. According to the limited metadata available this species likely occurs in the protected areas of Midongy du Sud and Andohahela. Fire (natural or man-made) and disturbance or elimination as a result of deforestation for agricultural extension are the major threats wich affect this species. Hence, it is assessed as Endangered B1ab(i,ii,iii,iv)+B2ab(i,ii,iii,iv).

\section{Notes}

One of only two short-leaved Costularia species in Madagascar; the other being C. humbertii. Costularia brevifolia is endemic to southeastern Madagascar, while C. humberti is endemic to 
the Marojejy National Park in northeastern Madagascar. Although both are likely related based on morphological resemblance, amplification of DNA extracted from the limited material available of $C$. brevifolia was unsuccessful, so a close relationship between the two short leaved species remains unconfirmed.

\section{Costularia cadetii Larridon sp. nov. -Figs. 8-10}

Type. LA RÉUNION, Saint-Benoît, Sainte-Rose, Pas de Bellecombe, 21¹3'21.38"S, 5541'17.27"E, 2328 m, 6 March 2017, J.I. Marquez-Corro et al. 04JMC17 (holotype K!, isotypes UPOS!).

Diagnosis: This species is closely related to C. humbertii from northern Madagascar, from which it differs in its smaller habit, absence of a caudex, the basal leaves equaling or overtopping the flowering culm, and having two bisexual flowers. It can be distinguished from the only other species of Costularia on La Réunion by its much smaller habit and having two bisexual flowers.

Small perennial herb, flowering culm up to $28 \mathrm{~cm}$, scarcely exceeding the leaves. Caudex absent or short (c. $0.5 \mathrm{~mm}$ wide). Culm slender, 4-12.5 $\mathrm{cm} \times 1.7-1.9 \mathrm{~mm}$. Basal leaves distichous; leaf sheaths $2.5-2.8 \mathrm{~cm} \times 6-7 \mathrm{~mm}$, reddish-purplish brown; leaf blades linear, flat, 8.5-29 $\mathrm{cm} \times 1.4-4 \mathrm{~mm}$, scabrid on the margins. Cauline leaves absent. Inflorescence a somewhat contracted panicle, $9-15.5 \times 1 \mathrm{~cm}$, composed of numerous spikelets; inflorescence bracts 5 , unequal, sheathing, dark reddish brown, scabrid on the margins; longest bract 8.5-13 $\mathrm{cm} \times 2-3 \mathrm{~mm}$. Peduncles unequal, up to $4 \mathrm{~cm}$ long, margins scabrid at least near the apex. Pedicels of the spikelets unequal, 1-12 mm long, minutely papilose, margins scabrid. Spikelets lanceolate, 4.5-5 × 1.1-2 mm, dark purple. Glumes distichous, narrowly ovate, boatshaped, acuminate to long mucronate (up to c. $1 \mathrm{~mm}$ ), 3.5-4.5 $\times 1.8 \mathrm{~mm}$, dark purple with pale lower third and pale mucro, scabrid to minutely ciliate on the margins, keel and top half of abaxial surface; 2-3 lower glumes empty, 2 upper glumes fertile. Flowers 2, both bisexual. Perianth bristles 6 , pale, antoresly ciliate. Stamens 3, anthers linear, 1-2 mm long with short conical connective. Style deeply trifid. Nutlet rounded trigonous, obovate, dark brown with 3 pale bands on the ridges, base attenuate $1.3-1.5 \times 0.8-0.9 \mathrm{~mm}$.

\section{Distribution}

Costularia cadetii is a small perennial herb, endemic to La Réunion and found only in the Parc National de La Réunion at elevations of 1700-2400 m (Fig. 10).

\section{Ecology}

Found growing in rocky areas, montane grasslands and ericoid vegetation close to volcanic crater edges at high elevation.

\section{Phenology}


Flowering specimens were collected in January, fruiting specimens in February and March. The specimens collected by Cadet in May had shed their glumes and nutlets, while the plants collected in November and December were vegetative or immature.

\section{Etymology}

The first record of this species (Cadet 454) was collected by in 1965, and on its label the following note is written “Costularia sp. Further material needed!”. Thérésian Cadet (19371987) was a botanist from La Réunion specialised in the vegetation from the Mascarene Islands. He taught plant biology at the University of La Réunion and was one of the main authors of the Flore des Mascareignes. This species is named in his honour.

\section{Conservation status}

Costularia cadetii is a small perennial herb, endemic to La Réunion. It is known only from three locations within the Parc National de La Réunion. The area, extent and quality of habitat of this species is threatened by fire, volcanic activity and climate change. Based on the seven known herbarium collections, the minimum estimated area of occupancy is $20 \mathrm{~km}^{2}$ and the minimum estimated extent of occurrence is $250 \mathrm{~km}^{2}$. It is hence categorised as Endangered B1ab(iii)+B2ab(iii).

\section{Notes}

Although not closely related to it, morphologically, $C$. cadetii most closely resembles the Madagascan endemic species $C$. andringitrensis, from which it can easily be distinguished by the former maturing two nutlets per spikelet.

\section{Costularia humbertii Bosser, Naturaliste Malgache 7: 121. 1955-Figs. 2, 11}

Type (lectotype designated here). Type.Madagascar, Antsiranana, Marojejy, 1850-2137 m, 26 March 1949 - 2 April 1949, H. Humbert \& G. Cours 23708 (lectohøløtype: MNHN-PP00459980!; isolectotypes: MNHN-P-P00459978!, MNHN-P-P00459979!, G00406272!).

Robust perennial herb. Caudex robust, 5-10 cm × 1-2 cm. Culm 30-70 cm × 2-3 mm, compressed, smooth. Basal leaves distichous, flabellately arranged; leaf sheaths densely imbricate, 2-3 cm long, reddish brown to chestnut coloured; leaf blades leathery, falciform (sickle-shaped), flat, canaliculate, pale green, minutely papillose above, $7-15 \mathrm{~cm} \times 5-8 \mathrm{~mm}$, much shorter than the culm, apex subacute to rounded-obtuse, margins scabrid. Cauline leaves 1-3, sheathing. Inflorescence a somewhat lax and compound panicle, foliate, $15-25 \mathrm{~cm}$ long, composed of 5-7 erect to flexuous fascicles. Peduncles unequal, at most $7 \mathrm{~cm} \mathrm{long,} \mathrm{margins}$ scabrid, papillose above. Pedicels of the spikelets 1-4 mm long, green. Spikelets lanceolate, 5$7.5 \mathrm{~mm}$ long, dark purple. Glumes 4-6, ovate, distichous, 1-veined, 4-5 × 1 mm, margins minutely ciliolate, keel somewhat scabrid, apex acute to mucronate, 2-4 lower glumes empty, 2 upper glumes fertile. Flowers 2, lower male, upper bisexual. Perianth bristles 6, longer than the 
nutlet, shortly ciliate. Stamens 3, anthers long and linear, apiculate, $3 \mathrm{~mm}$ long. Style deeply trifid. Nutlet $2.5 \mathrm{~mm}$ long, smooth, castaneous, trigonous, base attenuate, beak pale, $1 \mathrm{~mm}$, ciliolate.

\section{Distribution}

Endemic to the Antsiranana province of Madagascar where it is restricted to the high-elevation zone of the Marojejy National Park (Fig. 2).

\section{Ecology}

Found growing in swamps in high elevation ericoid vegetation, and on gneiss and quartzite rocks of the mountain ridge, at elevations of 1400-2200 m.

\section{Phenology}

Flowering specimens were collected in March to early April. Young inflorescences can be observed on the specimens collected in November-December.

\section{Conservation status}

Costularia humbertii is endemic to the Antsiranana province of Madagascar and is limited in distribution to the high-elevation zone of the Marojejy National Park. The minimal area of occupancy was calculated as $24 \mathrm{~km}^{2}$, the estimated extent of occurrence is $17 \mathrm{~km}^{2}$ and the species is only known from one location. Fire (natural and man-made) and disturbance of its habitat as a result of logging, firewood collection and charcoal are the major threats which may affect this species. Costularia humbertii is only known from seven herbarium collections and has not been collected since 1989. Research is needed to investigate its current status at the single known location. Here, we assess the species as Critically Endangered B1ab(i,ii,iii).

\section{Notes}

One of two short leaved Costularia species in Madagascar, the other being C. brevifolia. In the molecular phylogenetic hypothesis (Fig. 1), C. humbertii appears to be closely related with a small high-elevation species from La Réunion (C. cadetii).

\section{Costularia itremoensis Larridon sp. nov. -Figs. 5, 12}

Type. Madagascar, Fianarantsoa, Isalo Plateau, W of Ranohira, sandstone rocks, 800 1000 m, 30 July 1928, H. Humbert \& C.F. Swingle 4995 (holotype: MNHN-P-P0318446!, isotypes: $\mathrm{K}$ !, TAN).

Diagnosis: This species resembles most closely Costularia pantopoda var. pantopoda from which it can be distinguished by having longer peduncles (longest $5.5-11 \mathrm{~cm}$ vs. $4-5 \mathrm{~cm}$ ) and more emptyglumes (6-11 vs. 3-6). 
Medium-sized to tall perennial herb, up to c. $1.4 \mathrm{~m}$. Culm $17-68 \mathrm{~cm} \times 1.7-3.5 \mathrm{~mm}$. Basal leaves distichous; leaf sheaths 2-6 cm $\times 7-11 \mathrm{~mm}$, reddish-brown, sometimes burnt old leaf bases present; $20-70 \mathrm{~cm} \times 2.5-5.5 \mathrm{~mm}$, flat, margins scabrid. Cauline leaves $1-2$, margins scabrid, sheaths brownish. Inflorescence a panicle, somewhat contracted when young, but more lax at maturity, 24-68 cm long; inflorescence bracts 6-8, unequal, up to $4 \mathrm{~mm}$ wide, sheating, reddish, margins scabrid. Peduncles longest $5.5-11 \mathrm{~cm}$, unequal, flattened, margins scabrid. Pedicels of the spikelets erect, 2-11 mm, margins scabrid. Spikelets oblanceolate, (4.5-)5.5-10 $\times$ 1.2-2.8 mm. Glumes 8-13, distichous, the largest 4-6.5 mm long, dark purple above pale below; lower 6-11 glumes empty, acute, increasing in length; upper 2 glumes fertile, more obtuse. Flowers 2, lower male, upper bisexual. Perianth bristles 6, plumose, long antrorsly ciliate. Stamens 3; anthers 6-6.5 mm, linear. Style trifid, long. Nutlet rounded trigonous, $2.4 \times 1.2 \mathrm{~mm}$; beak c. $0.5 \mathrm{~mm}$, pale, ciliate.

\section{Distribution}

Costularia itremoensis is endemic to Madagascar and is found in the highlands of South Central Madagascar, in the Fianarantsoa province (Fig. 5).

\section{Ecology}

The habitat in which this species is found consists of bare rocks and/or grassland in the Itremo massif (L. Rabarivola, pers. obs.). In Isalo, its habitat is dominated by wooded grasslandbushland mosaic and/or plateau grassland-wooded grassland mosaic (Moat \& Smith, 2007) between 800 and $1700 \mathrm{~m}$ in elevation.

\section{Phenology}

Flowering/fruiting specimens were collected from July to September, plants collected in January to April were immature.

\section{Conservation status}

Costularia itremoensis is endemic to Madagascar and is found in the highlands of South Central Madagascar, in the Fianarantsoa province. Based on the limited metadata available it likely occurs in the Itremo new protected area and Isalo National Park. The estimated extent of occurrence was calculated as $7169 \mathrm{~km}^{2}$ and the minimal area of occupancy is $20 \mathrm{~km}^{2}$. This species is only known from three locations and is threatened by grazing and uncontrolled fire from pastures fire. Its habitat is also threatened by deforestation from logging, firewood collection and mining. Therefore, this species is assessed as Endangered: EN B2ab(i,ii,iii).

\section{Notes}

Costularia itremoensis is sister to a clade including C. leucocarpa + C. andringitrensis and $C$. natalensis (Fig. 1). 
7. Costularia leucocarpa (Ridl.) H.Pfeiff., Repert. Spec. Nov. Regni Veg. 23: 346. $1927 \equiv$ Rhynchospora leucocarpa Ridl., J. Linn. Soc., Bot. 20: $335.1883 \equiv$ Costularia recurva C.B.Clarke, Ill. Cyper.: t. LXXXVIII (1909), nom. superfl. $\equiv$ Tetraria leucocarpa (Ridl.) T.Koyama, J. Fac. Sci. Univ. Tokyo, Sect. 3, Bot. 8: 75. 1961-Fig. 13, 14

Type (lectotype designated here). Madagascar, Central Madagascar, R. Baron 399 (helelectotype K000244883!; isolectotypes BM, K!, MNHN-P-P00459985!).

= Cladium fimbristyloides Baker, J. Linn. Soc., Bot. 22: 531. 1887. Type (lectotype designated here). Madagascar, Central Madagascar, R. Baron 4193 (holelectotype

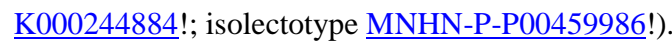

Perennial herb up to c. $1 \mathrm{~m}$ tall with a woody rhizome (c. $4 \mathrm{~mm}$ diam.), caudex sometimes present (c. $7 \mathrm{~mm}$ diam.) covered in old leaf sheaths. Culm strong but slender towards the apex, 38-60 cm $\times 1.9-2.6 \mathrm{~mm}$ diam., compressed to obtuse angled, grooved, minutely papillose. Basal leaves many, distichous; leaf sheaths brown-purplish, 3.5-4.5 cm long; leaf blades long acuminate, flat, margins scabrid. Cauline leaves 2, longest up to c. $35 \mathrm{~cm} \times 3 \mathrm{~mm}$, keeled, sheaths long somewhat enlarged, purplish, mouth obliquely cut. Inflorescence a semicompound panicle, 40-70 cm long, narrow, lax, built up out of 8-9 widely spaced fascicles; inflorescence bracts leafy and much overtopping the fascicles, sheath long and brown-purplish. Peduncles unequal, up to c. $10 \mathrm{~cm}$ long, flattened, scabrid. Pedicels of the spikelets (2-)4-10 mm long, arched recurved, scabrid. Spikelets oblong-lanceolate, subterete, 3.8-5 × $2 \mathrm{~mm}$. Glumes (56(-7), distichous, ovate, subobtuse, above dark purplish, below straw-coloured, nerveless except the keel, finely ciliolate, 3-3.5 × 1.7-2.4 mm; 3-5 lower glumes empty, increasing in size; 2 upper glumes fertile. Flowers 2, lower male, upper bisexual. Perianth bristles $6, \pm$ as long as the nutlet including its beak, tender, pale brown, antrorsely dense and shortly ciliolate, not plumose. Stamens 3, filaments and anthers reddish, anthers linear, connective short, wide pyramidal, dark purplish. Style rigid, brown, trifid, thickened at base, swollen in the middle, triquetrous, darkpurple, hairy, persistent. Nutlet 2.3-2.7 × 1.5-1.7 mm swollen-trigonous, pale, bright, smooth, hardly furrowed; beak narrow, $2-2.5 \mathrm{~mm}$ long.

\section{Distribution}

Endemic to Madagascar, found in the provinces Antananarivo, Antsiranana, Fianarantsoa, Toamasina and Toliara (Fig. 14).

\section{Ecology}

The species occurs at mid to (very) high elevation, and has been collected along mountain ridges, from thickets on rock formations, and in open forest.

\section{Phenology}

Flowering specimens were collected in December-January, while fruiting specimens were collected in February and March. 


\section{Conservation status}

Costularia leucocarpa is endemic to Madagascar and found in Antsiranana, Antananarivo, Toamasina, Fianarantsoa and Toliara provinces, where it has been collected along mountain ridges, from thickets on rock formations. The species occurs in Ranomafana National Park, Tsaratanana Reserve Naturelle Intégrale and Manongarivo Special Reserve. The species has a large distribution range $\left(\mathrm{AOO}=124 \mathrm{~km}^{2}\right)$ and its estimated $\mathrm{EOO}$ is $76,36 \mathrm{~km}^{2}$, which is much larger than the threshold for a threatened category. Despite its habitat being under various anthropogenic pressures, Costularia leucocarpa is here assessed as Least Concern because (1) no specific threats to its survival have been observed, (2) it is widely distributed in Madagascar, and (3) occurs in several protected areas.

\section{Notes}

Since Costularia recurva shares syntypes with the older name C. leucocarpa, both can be lectotypified to the same specimen (Baron 399 K000244883) rendering C. recurva superfluous.

Previously, the number and position of flowers has been unclear. Chermezon (1937) (in general for the genus) and Kükenthal (1939) (for C. leucocarpa) described the male flower to be born by the third glume from the top of the spikelet, the bisexual flower to be born by the second glume from the top, and the topmost glume to be empty and reduced. At first glance, this appears correct, but when comparing C. leucocarpa spikelets with those of the other Costularia species where the topmost glumes are fertile and the lower glumes are sterile, and taking in consideration the common metatopic displacement (epicaulescence) of the glumes and flowers on the rachilla in spikelets with distichous glumes of species of Cyperaceae subfamily Cyperoideae (Vrijdaghs et al., 2010, 2011), we believe that $C$. leucocarpa represents the common pattern observed in the rest of the genus.

8. Costularia melicoides (Poir.) C.B.Clarke, Bull. Misc. Inform. Kew, Addit. Ser. 8: 48 (1908). $\equiv$ Cyperus melicoides Poir. in J.B.A.M.de Lamarck, Encycl. 7: 273 (1806) $\equiv$ Machaerina melicoides (Poir.) Bojer, Hortus Maurit.: 386 (1837) EAsterochaete elongata Kunth, Enum. Pl. 2: 312 (1837) Schoenus elongatus Willd. ex Kunth, Enum. Pl. 2: 312 (1837), nom. inval. $\equiv$ Carpha elongata (Kunth) Boeckeler, Linnaea 38: 273 (1874) $\equiv$ Cyclocampe elongata (Kunth)

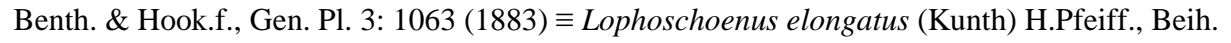
Bot. Centralbl. 44(1): 133 (1927) $\equiv$ Costularia elongata (Kunth) Kük., Repert. Spec. Nov. Regni Veg. 44: 187 (1938), nom. illeg. $\equiv$ Tetraria elongata (Kunth) T.Koyama, J. Fac. Sci. Univ. Tokyo, Sect. 3, Bot. 8: 74 (1961)-Fig. 10

Type (lectotype designated here). Type. Mauritius, L.M.A. du Petit Thouars s.n. (herb. Willd. 1115 fol. 1) (lectoholetype MNHN-P-P00552880!, isolectotype MNHN-P-P02284597!). = Carpha costularioides C.B.Clarke, Bull. Misc. Inform. Kew, Addit. Ser. 8: 43 (1908) (earlier as Carpha aubertii Nees var. explicatior C.B.Clarke, Consp. Fl. Afr. 655 (1894), nom. inval. with mention of type but no description) $\equiv$ Costularia explicatior Cherm., Bull. Soc. Bot. 
France 69: 722 (1922). Lectotype (designated here). Mauritius, Flacq, Le Grand Fond, 280 m, 17 June 1890, H.H. Johnston s.n. (lectoholetype K000244879!, isolectotype MAU0003574!).

Perennial herb with short rhizome with stiff fibres. Culm $35-100 \mathrm{~cm} \times 1.5-4 \mathrm{~mm}$, striate, minutely puncticulate. Basal leaves crowded, distichous; leaf sheaths $4-6 \mathrm{~cm}$ long, indistinct, straw-coloured to purple, multiveined; leaf blades c. $27-60 \mathrm{~cm} \times 2.5-5 \mathrm{~mm}$, flat, indistinctely keeled, tapered at the tip, edges minutely serrulate. Cauline leaves 3-4, very distant; leaf sheaths, long, green-purplish, mouth oblique. Inflorescence an elongate panicle, $30-85 \mathrm{~cm}$ long, with c. 9-11 partial inflorescences, distantly spaced; inflorescence bracts longer than the partial inflorescence they subtend, sheaths purplish. Peduncles unequal, up to c. $12 \mathrm{~cm}$. Pedicels of the spikelets erect, flattened, margins slightly scabrid, 4-15 mm long. Spikelets oblong-lanceolate, 5.5-7.5 × 1.5-2 mm, somewhat flattened. Glumes 5-8, distichous, lanceolate-ovate, acuminate, reddish-black, with colourless-whitish margins; lower glumes empty, scabrid on the midvein, mucronatae-aristulate; 2 upper glumes fertile, barely mucronate; rhachilla short and erect.

Flowers 2, lower bisexual, upper male. Perianth bristles 6, longer than the nutlet, pale to rustycoloured, antrorsely densely ciliate-scabrid. Stamens 3; anthers linear yellow; connective short, bent, purple. Style trifid, base elongate-conical, triquetrous, pale, margins hispidulous, persistent. Nutlet swollen-trigonous, longitudinaly trisulcate, pale, smooth, 2-2.3 mm long, base long cuneate; beak narrow, 2-2.5 mm long.

\section{Distribution}

Endemic to the Mascarene Islands of La Réunion and Mauritius (Fig. 10).

\section{Ecology}

Costularia melicoides prefers mid to higher elevation on the island of La Réunion: (500-)9001700 (-2000) $\mathrm{m}$ where it occurs in ericoid thickets (avounes), moist tropical forest, forest with Acacia heterophylla (tamarinaie), and humid tickets with Pandanus (C. Fontaine pers. comm.). However, in Mauritius, it is found on boulders or in clumps in seasonally-flooded upland marshes near Petrin in the Black River Gorges National Park at elevations of c. 600-700 m, in upland marshes and thickets in Perrier Nature Reserve at c. $550 \mathrm{~m}$ in elevation, and in the district Flacq it was found at an elevation of $280 \mathrm{~m}$.

\section{Phenology}

Flowering specimens were collected in February (La Réunion) and June (Mauritius), fruiting specimens were collected in April and May and from October to January (La Réunion).

\section{Conservation status}

Costularia melicoides occurs in the four regions of La Réunion, and it has been recorded from two regions of Mauritius (Flacq and Plaines Wilhems). Likely, the location at Flacq does not exist anymore (C. Baider, pers. observ.). The species prefers mid to higher elevations on La Réunion, while it it is found at lower elevations on Mauritius. It grows in ericoid thickets, 
forests, on boulders or in clumps in seasonally-flooded upland marshes. Its area of occupancy was estimated as $64 \mathrm{~km}^{2}$ and its extent of occurrence as $6805 \mathrm{~km}^{2}$, and it occurs at four locations (the Parc National de La Réunion, and in the Black River Gorges National Park, the Perrier Nature Reserve and the protected areas of the Bambou Mountains on Mauritius). The habitat of the species in Le Réunion is threatened by invasive alien species, disturbance due to human activities, and climate change. In Mauritius, similar threats to the habitat of the species exist, in particular due to invasive alien species and the patchiness of the remaining native vegetation. Therefore, Costularia melicoides is here assessed as Endangered EN B2ab(i,ii,iii,iv).

\section{Notes}

In Costularia melicoides, the lower fertile flower is bisexual and the upper fertile flower is male (or sterile), in contrast with the mainland African and Madagascan Costularia species (with lower fertile flower male or sterile, and upper fertile flower bisexual), and in contrast with $C$. cadetii from La Réunion with two bisexual flowers.

\section{Notes}

All specimens included in the molecular phylogenetic study were collected in La Réunion.

\section{Costularia melleri (Baker) C.B.Clarke ex Cherm., Cat. Pl. Madag., Cyper. 40. 1931} (Costularia melleri C.B.Clarke, Consp. Fl. Afr. 5: 658. 1894, nom. inval.) E Cladium melleri Baker, J. Linn. Soc., Bot. 21: 451. $1885 \equiv$ Mariscus melleri (Baker) Fernald, Rhodora 25: 54. $1923 \equiv$ Machaerina melleri (Baker) T.Koyama, Bot. Mag. (Tokyo) 69: 64. $1956 \equiv$ Tetraria melleri (Baker) T.Koyama, J. Fac. Sci. Univ. Tokyo, Sect. 3, Bot. 8: 75. 1961-Fig. 2

Type (lectotype designated here). Madagascar, Antananarivo, between Toamasina and Antananarivo, July-August 1862, C.J. Meller s.n. (holølectotype: K000244888!, isolectotype: MNHN-P-P00459987!)

Perennial herb up to $180 \mathrm{~cm}$ tall with a short, woody rhizome. Culm $80-100 \mathrm{~cm} \times 4-9$ $\mathrm{mm}$, robust, slightly compressed, smooth-grooved, tapering to the top. Basal leaves leathery; leaf blades 30-36 cm $\times 7-15 \mathrm{~mm}$, flat or with inrolled edges, margins scabrid, tapering strongly above the leaf sheaths, very acute; leaf sheaths much broader, 8-10 $\times 3.5 \mathrm{~cm}$, dark brownpurplish. Cauline leaves 3, up to c. $35 \mathrm{~cm}$, widely spaced; sheaths scarcely enlarged brownishgreen base brown, edge obliquely cut. Inflorescence a large panicle, 60-100 cm long, up to c. 5$7 \mathrm{~cm}$ wide; inflorescence bracts 9-11, sheathing, dark brown-purple. Peduncles unequal, up to $12 \mathrm{~cm}$ long, quite robust, flattened, margins scabrid. Pedicels of the spikelets $3-5 \mathrm{~mm}$ long, flattened, margins scabrid, \pm curved. Spikelets very numerous, linear-oblong, 7-10 $\times 1-1.5 \mathrm{~mm}$. Glumes 16-18, pale reddish or light reddish brown with hyaline margins, obtuse, lower 14-16 empty, upper 2 fertile; lower empty glumes very small, increasing in size towards top of spikelet; top glume somewhat reduced, pale, narrow. Flowers 2, lower male or sterile, upper bisexual. Perianth bristles 6, 2-3 times as long as the nutlet including its beak, rust-coloured, long ciliate, plumose. Stamens 3; anthers linear, shortly apiculate. Style trifid, long, hispidulous, pale brown, 
base pyramidal or triangular persistent. Nutlet obovoid, quite strongly trigonous, with canaliculate ribs, $1.5 \mathrm{~mm}$ long, rugulose, reddish brown; beak $1 \mathrm{~mm}$ long.

\section{Distribution}

Endemic to Madagascar, occurring in the provinces Antananarivo, Fianarantsoa and Toamasina (Fig. 2).

\section{Ecology}

Marshes, humid areas in forest, an elevation of 1000-1500 m.

\section{Phenology}

Specimens with very young inflorescences were found in October, November and April, flowering specimens were collected in November and January, fruiting specimens in December. Specimens collected in March and April had already lost their ripe nutlets.

\section{Conservation status}

The conservation status of Costularia melleri was previously assessed by Faranirina (2017) as Endangered B2ab(i,ii,iii,iv,v) based on an estimated AOO of $45 \mathrm{~km}^{2}$ (within the limits for Endangered status under the criterion B2) and five known locations. Only one subpopulation occurs in a protected area (Ranomafana National Park; Larridon et al. 2010-0249), the other subpopulations are known from unprotected areas subject to agriculture activity (Faranirina, 2017). Faranirina (2017) projected that the ongoing loss of its habitat will induce a strong continuous decline in the number of subpopulations and mature individuals in the next ten years as well as a continuing decline in its $\mathrm{EOO}$ and $\mathrm{AOO}$.

\section{Notes}

Several specimens (i.e. Baron 1026, Baron 4104, Bosser 122, Decary 5826, Du Petit Thouars s.n. and Meller s.n.) have fewer glumes but represent very young plants. Clarke (1894) did not validly publish the combination Costularia melleri. He stated it to be a "sp. nov.", although he cited the three syntypes of Cladium melleri Baker (Baron 1026, Baron 2846 and Meller s.n.) and a $4^{\text {th }}$ specimen (Baron 4104). The name lacks any reference to the basionym ICN Art 41.1 and lacks any form of description, so this does not constitute valid publication of the combination according to Art. 41.4 (Turland et al., 2018).

10. Costularia microcarpa (Cherm.) Kük., Repert. Spec. Nov. Regni Veg. $46: 69$ (1939) $\equiv$ Costularia baronii var. microcarpa Cherm., Bull. Soc. Bot. France 72: 617 (1925) -Fig. 5 Type (lectotype designated here). Fype:-Madagascar, Fianarantsoa, Isalo, $1000 \mathrm{~m}$, isolectotypes: MNHN-P-P00459969!, MNHN-P-P00459970!, MNHN-P-P00459971!). 
Very robust and tall perennial herb. Culm robust, $1.2-2 \mathrm{~m} \times \mathrm{c} .6 \mathrm{~mm}$-wide. Basal leaves firm, long, $5 \mathrm{~mm}$ wide, flat, edges denticulate, involute, long attenuated; leaf sheaths up to $9 \mathrm{~cm}$ $\times 8-10 \mathrm{~mm}$, brownish. Inflorescence a long, dense and complex panicle, built up from multiple branched fascicles; inflorescence bracts setaceous, shorter than fascicles, sheaths long and brown. Peduncles longest c. $7.5 \mathrm{~cm}$. Pedicels of the spikelets $2-4 \mathrm{~mm}$ long, curved. Spikelets very numerous, most individually pedicellate, less often sessile, oblong $\pm 6-7.5 \times 1-1.5 \mathrm{~mm}$, subterete, arcuate. Glumes subdistichous, coriaceous, straw-coloured to purplish-striate; lower 610 glumes empty, ovate, subobtuse, with sparsely ciliolate margins; upper 2 fertile glumes lanceolate, acute, the topmost glume somewhat reduced. Flowers 2, lower male, upper bisexual. Perianth bristles 6, overtopping the nutlet, plumose from base to tip. Stamens 3. Style long, trifid, base thickened, hispidulous apex persistent. Nutlet obovate swollen-trigonous, $2 \mathrm{~mm}$ long, base attenuate, reddish, slightly rugulose.

\section{Distribution}

Endemic to the Ihorombe Haute Matsiatraregion of Fianarantsoa province in Madagascar (Fig. $5)$.

\section{Ecology}

Found growing on shaded, humid sandstone in Isalo National Park at an elevation of c. $1000 \mathrm{~m}$.

\section{Phenology}

Only known specimen was collected in October as flowering.

\section{Conservation status}

Costularia microcarpa is endemic to Madagascar. It is only found in Ihorombe region of Fianarantsoa province at elevation $1000 \mathrm{~m}$ in Isalo National Park. There is insufficient information available to assess the conservation status of this species since it is only known from its type specimen. Therefore, it is categorised as Data Deficient. Research is needed to investigate whether the population of this species at the only known location in Isalo National Park is still present.

\section{Notes}

This is one of only two Costularia species that could not be sampled for this study, as it is only known form the type specimen. Although unsure at this time, this species is likely part of the $C$. pantopoda species complex. Chermezon (1937) originally published this as a variety under $C$. pantopoda subsp. baronii (as C. baronii var. microcarpa) though Kükenthal (1939) later recognised this taxon at species level.

11. Costularia natalensis C.B.Clarke, Consp. Fl. Afr. 5: 658 (1894)—Figs. 15, 16 
Type (lectotype designated here). South Africa, KwaZulu-Natal, [without stated locality but probably Noodsberg (Burtt, 1988; Browning \& Gordon-Gray, 1996)], J. Buchanan 152 (lectotype: K000244893!).

Adapted from Browning \& Gordon-Gray (1996): Perennial herb up to $2.5 \mathrm{~m}$ tall, tufted; rhizome $1-1.5 \mathrm{~mm}$ in diameter, woody, erect, clothed in thick adventitious roots. followed by coarse, persistent leaf bases up to $15 \mathrm{~mm}$ wide. Culm erect, $50-150 \mathrm{~cm}$ in lengthtall including inflorescence, $2.5-4.5 \mathrm{~mm}$ wide, , Basal leaves spirodistichous; leaf sheaths elothed basally in persistent, up to $15 \mathrm{~mm}$ wide; brittle, dead, spirodistichously arranged leaf bases that grade inte the basal leaves, nodose; nodes dark chestnut brown to blackish red, occasionally light brown; internodes subtrigonous, slightly flattened or terete, hard, glabrous, glaucous-green. Basal leaves numerous with sheaths poorly defined, short in relation to blade length; leaf blades 30-60 cm $\times$ (1.5-)3-4 mm, gradually tapering to elongate curling apices $\pm 1 \mathrm{~mm}$ wide, tough, glabrous, margins scabrous. Cauline leaves 2-4, with sheaths closed, enveloping up to half of internode length, mostly green except for narrow brown membranous margin to long narrow $V$ shaped mouth; blades smaller than those of the basal leaves and size decreasing towards the apex of the eulm. Inflorescence a panicle of closely packed, erect spikelets grouped in \pm elongated irregular clusters or appearing interrupted with \pm nodding clusters if inflorescence branches and peduncles are long and droop with weight of maturing spikelets and rainwater (robust plants), 55-95 cm long; inflorescence bracts 4-8(-12), dark chestnut brown to blackish-red, reducinged in size upwards-so that most distal bract apices only shortly surpass spikelet clusters. Peduncles unequal, up to c. $16 \mathrm{~cm}$ long, flattened, scabrid on the margins. Pedicels of the spikelets 2.5-6 $\mathrm{mm}$ long, straight to curved, very scabrid. Spikelets oblong, 6-9 $\times 1.8-2.0 \mathrm{~mm}$, dull dark brown. Glumes subdistichous, 6-12, lower 3-9 empty, of which lowest 1-3 frequently with apex attenuate, remainder increasing in length upwards, apices acuminate or acute, next 3 largest, 6-7 $\times 3 \mathrm{~mm}$, boat-shaped, glabrous except for well-marked ciliate margin, apex obtuse, toothed, but rolled so appearing narrow, and almost acute until unfolded, uppermost glume enclosed within the two preceding, slightly shorter. Flowers 2 , lower male, upper bisexual. Perianth bristles 6 , delicate, 6-7 mm long, white, villous in distal half. Stamens 3, filaments persistent 5-7 mm long after anthesis, ribbon-like; anthers linear-oblong, large, apiculate, early deciduous. Style trifid, dark brown, coarsely plumose, proximal portion of style persistent as short to long beak on fruit. Nutlet rounded trigonous, narrowed basally into funnel-shaped extension $\pm 1 / 4$ length of globose portion, $5 \times 3 \mathrm{~mm}$ in total length and width, faintly 3-ridged longitudinally, whitish to pale fawn; surface smooth to slightly transversely rugose.

\section{Distribution}

Costularia natalensis is restricted in its distribution to southeastern Africa (Fig. 16). In particular, the species is present at higher elevation (1070-2130 m) along the chain of individually isolated highlands roughly paralleling part of the coastline, e.g. in South Africa the Wolkberg, Sabie and Graskop areas of the Mpumalanga Drakensberg (Browning \& GordonGray, 1996). Mount Mulanje in Malawi is the northernmost known locality, and the 
southernmost distribution of the species reaches the area of Pietermaritzburg in Kwazulu-Natal (South Africa).

\section{Ecology}

According to observations by Browning \& Gordon-Gray (1996), populations are mostly very localised, often small, and in KwaZulu-Natal, frequently limited to a few scattered, solitary plants which grow on steep, rocky slopes, associated with coarse grasses in the zone between forest and grassland. A slightly more extensive population grows along banks of small streams and among boulders, where nutrients particularly phosphates are in short supply and other vegetation is scare (Restionaceae and short grasses), in the Chimanimani National Park (Zimbabwe; Browning \& Gordon-Gray, 1996). In Mozambique, several (small) subpopulations are also found on quartzite sandstone in the Chimanimani Mts, and on rocks in the submontane grasslands of Mt Gorongosa and Serra Choa. Plants of this species have been collected from Mount Mulanje in Malawi (which is composed of seynite, quartz-seyinite and granite rock materials), in particular from the eastern zone of the Biosphere Reserve (Lichenya and Chambe). It is restricted to higher elevations.

\section{Phenology}

Flowering/fruiting specimens were collected from November to May.

\section{Conservation status}

Costularia natalensis is restricted in its distribution to southeastern Africa (Malawi,

Mozambique, Zimbabwe, Swaziland, South Africa). It is found at higher elevations in rocky areas in grassland and shrubland. Threats affecting part of the range of the species include fire, fuelwood collection, illegal logging of natural forests and plantation forestry, invasive species and potential mining. Although the population of this species is believed to be decreasing (Browning \& Gordon-Gray, 1996), it currently does not fall within the criteria for any of the threat categories, and is therefore assessed as Least Concern. However, further research is needed to investigate threats and population size.

\section{Notes}

In our molecular phylogenetic results (Fig. 1), C. natalensis is found in a clade with three other Costularia species, two of which are here described as new to science, i.e. C. andringitrensis and C. itremoensis. Although Burtt (1988) indicated some morphological variety between plants of different localities, Browning \& Gordon-Gray (1996), who studied specimens from the entire distribution range of $C$. natalensis, found no clear discontinuities that may provide a basis for subdivision of the species. 
pantopodus (Baker) Fernald, Rhodora 25: 54. 1923 = Machaerina pantopoda (Baker) T.Koyama, Bot. Mag. (Tokyo) 69: 65. $1956 \equiv$ Tetraria pantopoda (Baker) T.Koyama, J. Fac. Sci. Univ. Tokyo, Sect. 3, Bot. 8: 75. 1961.

Type (implicitly lectotypified by Clarke 1894: 658). Madagascar, Central Madagascar, $R$. Baron 2072 (holotypelectotype: K000244886!, isolectotypes: K001322342!, K!, MNHN-P$\underline{\mathrm{P} 00459988 !}$ ).

\section{Conservation status}

Costularia pantopoda is restricted in its distribution to south-central Madagascar, and occurs in at least one protected area, i.e. the Andringitra National Park. Threats to this taxon need further investigation but in the Andrigitra National Park, where most collections have been made, its habitat and area of occupancy are impacted negatively by cattle grazing and by fires started for pastoral reasons which can easily get out of control and enter the National Park (I. Larridon, pers. obs. 2010; F. Rakotonasolo, pers. obs. 2017). In other areas, fire (natural and man-made) and disturbance of its habitat as a result of logging, firewood collection and charcoal may also affect this species. Based on 10 georeferenced herbarium specimens, the taxon occurs in at least six locations and has an estimated AOO of $40 \mathrm{~km}^{2}$ and an EOO of $9478 \mathrm{~km}^{2}$. Using IUCN criteria, this variety can be assessed as VU B1ab(ii,iii)+2ab(ii,iii).

\section{2a. Costularia pantopoda (Baker) C.B.Clarke ex Cherm. var. pantopoda-Figs. 5, 17, 18}

Medium-sized perennial herb, up to c. $65 \mathrm{~cm}$ height. Culm $25-30 \mathrm{~cm} \times 2.5-3 \mathrm{~mm}$. Basal leaves distichous; leaf sheaths 6-7 (-9) $\times$ c. $2 \mathrm{~cm}$, brownish-purple, very wide compared to the leaf blades; leaf blades usually enrolled and thus appearing much narrower than the leaf sheaths, 1-4 mm wide when enrolled, up to c. $7 \mathrm{~mm}$ when flattened, leathery, margins scabrid. Cauline leaves 1-2, 5-7 mm wide margins scabrid, sheaths brownish. Inflorescence a panicle 10-35 cm long, quite tight, narrow; inflorescence bracts 5-10, brown to dark purple. Peduncles longest 4-5 $\mathrm{cm}$, erect to arching downwards, flattened, margins scabrid. Pedicels of the spikelets erect, 2-6 $\mathrm{mm}$, margins scabrid. Spikelets lanceolate, 6-7.5 × 1.5-2.3 mm. Glumes 5-8, the largest 5-6.5 $\mathrm{mm}$ long, dark purplish-brown to nearly black, the lower 3-6 empty, ovate, scabrid on the keel, ciliolate at the apex, increasing in length; 2 upper flowering glumes ovate-lanceolate. Flowers 2 , lower male, upper bisexual. Perianth bristles 6, much longer than the nutlet, plumose, long ciliate. Stamens 3; anthers linear, shortly apiculate. Style trifid, long; style base hispidulous, triangular, persistent. Nutlet broad obovoid triangular, somewhat rugulose, $1.75 \mathrm{~mm}$; beak $1 \mathrm{~mm}$, almost as wide as the nutlet.

\section{Distribution}

Costularia pantopoda var. pantopoda occurs in the Fianarantsoa province and in the south of the Antananarivo province of Madagascar (Fig. 5).

\section{Ecology}


Rocky areas at high elevation (1300-2500 m).

\section{Phenology}

Flowering specimens were collected from December to April, fruiting specimens from September to November.

\section{Notes}

Baker (1885: 451) originally described Cladium pantopodum based on two specimens collected by Baron (2072 and 3316). In 1894, Clarke placed this species in Costularia and split it up into two species, i.e. Costularia pantopoda (Baron 2072) and Costularia C. baronii (Baron 3316, Baron 4517, Baron 5061, Scott Elliot 1989). However, and-Clarke (1894: 658) failed to provide a description for Costularia $\underline{C}$. baronii, this species was only made valid in Clarke (1898: 274) where he provides a short diagnosis for it at the end of his treatment of $C$. natalensis.

12b. Costularia pantopoda var. gracilescens Kük., Repert. Spec. Nov. Regni Veg. 41: 67 (1939) -Fig. 6

Type (lectotype designated here). Type-Madagascar, Antananarivo, Antsirabe, $1600 \mathrm{~m}$, January 1919, H. Perrier de la Bâthie 2729 (lectoholetype: P; isolectotype: K000244887!).

Culms slender, $0.9 \mathrm{~mm}$ wide. Basal leaves with the leaf sheath little larger than the narrow leaf blades (up to c. $1.5 \mathrm{~mm}$ wide). Inflorescence fairly contracted panicle, with fewer spikelets, and composed of 4-5 fascicles. Peduncles longest $8.5 \mathrm{~cm}$. Pedicels of the spikelets 2-8 $\mathrm{mm}$ long, flattened, margins scabrid. Spikelets $6-7 \times 1.5 \mathrm{~mm}$, purple. Glumes clearly distichous, lower 5-6 empty glumes mucronate to acute, upper 2 fertile glumes obtuse. Perianth bristles 6 , $5.5 \mathrm{~mm}$ long, pale to rusty-coloured, antrorsely ciliate. Stamens 3 ; anthers $3.5 \mathrm{~mm}$, linear, apiculate. Nutlet immature.

\section{Distribution}

Known from a single collection made near Antsirabe in the Antananarivo province of Madagascar (Fig. 5).

\section{Ecology}

The only known collection was found growing in a marsh at c. $1600 \mathrm{~m}$ in elevation.

\section{Phenology}

The taxon was collected in flower in January.

\section{Notes}


Kükenthal (1939) described this new variety based on a single specimen (Perrier de la Bâthie 2729). Though likely present in $\mathrm{P}$, the lectoholetype could not be traced. This variety most closely resembles Costularia pantopoda var. pantopoda.

\section{2c. Costularia cf. pantopoda-Figs. 5, 19}

Specimen. Madagascar, Toamasina, Ambatofinandrahana-Amborompotsy, Mountains W of Itremo (W Betsileo), 1500-1700 m, 17-22 January \& 18-22 April 1955, H. Humbert 30061 (MNHN-P-P01908604!)

\section{Notes}

A single specimen was collected from the mountains West of Itremo, at an elevation of 1500 to $1700 \mathrm{~m}$ outside of the Itremo protected area delimitation. Grazing, fire (natural and man made) to renew cattle pasture and mining are the major threats wich affect this habitat. This specimen appears as sister to $C$. pantopoda in the phylogenetic hypothesis (Fig. 1). This specimen shows some similarities with $C$. itremoensis (Figs. 12, 19).

13. Costularia purpurea Cherm., Bull. Soc. Bot. France 69: 722.1922 publ. $1923 \equiv$ Tetraria purpurea (Cherm.) T.Koyama, J. Fac. Sci. Univ. Tokyo, Sect. 3, Bot. 8: 75. 1961-Fig. 14

Type (lectotype designate here). Madagascar, Antananarivo, Analamanga, Manjakandriana, forest E of Ambatolaona, 1300-1450 m, 11 November 1912, R. Viguier \& H. Humbert 1231 (holelectotype: MNHN-P-P00459990!; isolectotypes: MNHN-P-P00459991!, MNHN-P-P00459992!).

= Costularia laxa Cherm., Bull. Soc. Bot. France 69: 723. 1922 publ. 1923 三 Tetraria laxa (Cherm.) T.Koyama, J. Fac. Sci. Univ. Tokyo, Sect. 3, Bot. 8: 75. 1961. Type (lectotype designated here). Madagascar, Antsiranana, Manongarivo, 1000 m, May 1909, H. Perrier de la Bâthie 2639 (holelectotype: MNHN-P-P00459983!; isolectotype: MNHN-P-P00459984!).

Perennial herb up to $2.5 \mathrm{~m}$ tall. Caudex covered in lateral roots can be present $(0.7-1.5$ $\mathrm{cm}$ in diam.). Culms more or less robust, $50-1.3 \mathrm{~m} \times 2.5-4 \mathrm{~mm}$. Basal leaves distichous; leaf sheaths $3.5-8.5 \mathrm{~cm} \times$ up to $9 \mathrm{~mm}$, brownish-purple; leaf blades leathery, (28-)50-80 $\mathrm{cm} \times 3-8$ $\mathrm{mm}$, flat or slightly inrolled, margins scabrid, tapering to a very acute tip. Cauline leaves $3-4$, far apart; sheaths long tubular, purplish or brownish-green, mouth obliquely cut. Inflorescence a quite narrow panicle with lax partial inflorescences to a lax complex panicle, 50-90(-165) cm long; inflorescence bracts 8-14; sheaths purple. Peduncles unequal, up to $13 \mathrm{~cm}$, flattened, margins scabrid. Pedicels of the spikelets 5-10(-25) mm flattened, margins scabrid, straight or curved. Spikelets oblong-lanceolate, very flattened, (4-)6-10 × (1.2-)2 mm. Glumes (dark) purple, ovate-lanceolate, (sub)acute, keel scabrid, edges minutely ciliate, (3-)5-9 lower glumes empty, 2 upper fertile, largest 4-5.5 mm long. Flowers (1-)2, either both bisexual (generally only lower perfecting a nutlet), or lower bisexual and upper functionally male, more rarely lower male and upper bisexual, or rarely a single bisexual flower. Perianth bristles 6, equalling or surpassing the nutlet, pale reddish-brown, plumose below, densely and shortly ciliolate above.
Formatiert: Englisch (Großbritannien)

Formatiert: Englisch (Großbritannien)

Feldfunktion geändert

Formatiert: Englisch (Großbritannien)

Feldfunktion geändert

Formatiert: Englisch (Großbritannien)

Formatiert: Englisch (Großbritannien) 
Stamens 3; anthers linear, reddish, connective very shortly apiculate. Style long, deeply trifid, thin, brownish; style base triangular, hispidulous, pale, persistent. Nutlet rounded-trigonous, (1.5-)2-3 mm $\times 1-1.5 \mathrm{~mm}$, greyish-brown, rugulose- reticulate, with an attenuate base; beak (1) $1.5-2.5 \mathrm{~mm}$ long, base as wide as the nutlet.

\section{Distribution}

Costularia purpurea is endemic to Madagascar, occurring in the Antananarivo, Antsiranana, Fianarantsoa, Toamasina and Toliara provinces (Fig. 14).

\section{Ecology}

The species is found infrequent on granitic formations in ericaceous shrubland, grassland and open forests at mid to high elevations (500-1850 m).

\section{Phenology}

Flowering/fruiting specimens were collected from November to May. Young inflorescences can be observed on the specimens collected in September-October, while old inflorescences remain on the plants until September.

\section{Conservation status}

The species occurs in a range of protected areas including: Analamazaotra (Périnet), Andohahela, Didy National Park (NP), Kalambatritra, Manjakatompo Ankaratra, Manongarivo Reserve, Marojejy NP, Masoala NP, and Ranomafana NP. Based on its known and projected distribution, it is likely also present in among others Midongy du Sud NP. Since no specific threats are known to the species, and because it has a wide distribution in Madagascar $(\mathrm{AOO}=$ $132 \mathrm{~km}^{2}, \mathrm{EOO}=218,948 \mathrm{~km}^{2}$ ) and occurs in a range of protected areas, Costularia purpurea is here assessed as Least Concern.

\section{Notes}

The specimen Hildebrandt $3752 a$ was listed as a syntype of $C$. recurva (accepted name $C$. leucocarpa) but conforms to circumscription of $C$. purpurea. A lot of confusion existed between $C$. leucocarpa and $C$. purpurea, with many $C$. purpurea specimens at the $\mathrm{G}, \mathrm{K}$ and $\mathrm{P}$ herbaria identified as $C$. recurva. However, these species are quite different in morphology, with $C$. purpurea characterised by longer, flatter, narrower, darker spikelets generally bearing more glumes compared to C. leucocarpa.

Most herbarium specimens listed as C. laxa by Chermezon (1937) and Kükenthal (1939) are very immature and difficult to identify. Although the clade with two accessions originally identified as C. laxa and three accessions identified as C. purpurea is well supported in the molecular phylogenetic hypothesis, the taxa themselves are not (Fig. 1). Chermezon (1937) and Kükenthal (1939) distinguished C. laxa from C. purpurea based on it laxer inflorescence, fewer empty glumes (3-4 vs. 5-9) and perianth bristles much overtopping the nutlets. However, this 
distinction does not hold as variation in inflorescence branching and number of spikelets per inflorescence is gradual, even in the specimens listed by Chermezon (1937) as C. laxa spikelets often have more than 4 empty glumes, and in Perrier de la Bâthie 2639 (MNHN-P-P00459983), selected as hololectotype of $C$. laxa, the size of the nutlets varies from 1.6-2 mm plus a beak of 0.7-1.3 which is not that much shorter than the perianth bristles and similar to many specimens conforming to the description of $C$. purpurea.

This species is sister to C. melicoides of the Mascarenes. Costularia melicoides is unusual in perfecting a nutlet in lower of the two fertile glumes, while most Costularia species perfect a nutlet in the upper fertile glume. In $C$. purpurea, the number and sex of the flowers is variable with many of the collected specimens also perfecting a nutlet in the lower fertile glume. These sister species also share a similar build and size.

Costularia laxa var. macrantha Cherm. (1925: 21) is here excluded from C. laxa as we consider it to be synonymous with $C$. robusta (see more discussion under that taxon).

14. Costularia robusta (Cherm.) Larridon, comb. et stat. nov. $\equiv$ Costularia baronii C.B.Clarke var. robusta Chermezon, Bull. Soc. Bot. France 69: 723 (1922) ECostularia pantopoda var. robusta (Cherm.) Kük., Repert. Spec. Nov. Regni Veg. 41: 68 (1939)—Fig. 5

Type. Madagascar. Antisiranana, Diana, [Tsaratanana Reserve, Maromokotro], 2700 m, December 1912, H. Perrier de la Bâthie 2503 (holotype: MNHN-P-P00459966!).

= Costularia laxa var. macrantha Cherm., Bull. Soc. Bot. France 72: 21. 1925. Type (lectotype designated here). Type:-MADAGASCAR, Antsiranana, Diana, [Tsaratanana Reserve, Maromokotro], 2000 m, Janaury 1923, H. Perrier de la Bâthie 15652 (holotypelectotype: MNHN-P-P00459967!; isolectotype: MNHN-P-P00459968!).

Very robust and tall perennial herb with a strongly developed and long (c. $1 \mathrm{~m}$ ) caudex. Culms 0.8-2 m × c. $6 \mathrm{~mm}$, robust. Basal leaves with very wide leaf sheaths (15-20 mm), persistent at the base of the culm above the caudex. Inflorescence an elongate, narrow panicle with very numerous, crowded spikelets; inflorescence brances erect, not more than $5 \mathrm{~cm}$ long. Pedicels of the spikelets short, not patent. Spikelets 6-7 mm long. Glumes 12-14, up to $7 \mathrm{~mm}$ long, purplish black.

\section{Distribution}

Costularia robusta is only known from the Manongarivo, Marojejy and Tsaratanana protected areas and their environs in the Antsiranana province of Madagascar (Fig. 5).

\section{Ecology}

This taxon occurs in ericoid shrublands at (very) high elevations (1400-2800 m).

\section{Phenology}

Inflorescences are initiated in April and flower/fruit between October and January. Old inflorescences are still visible on the plants in April when the new inflorescence are formed. 


\section{Conservation}

Costularia robusta is restricted in its distribution to the Antsiranana province of Madagascar, and occurs in at least three protected areas, i.e. Manongarivo, Marojejy and Tsaratanana. Threats to this taxon need further investigation but fire (natural and man-made) and disturbance of its habitat as a result of logging, firewood collection and charcoal may affect this species. Based on 11 georeferenced herbarium specimens, this species occurs in at least six locations and has an estimated AOO of $28 \mathrm{~km}^{2}$ and an EOO of $2947 \mathrm{~km}^{2}$. Using IUCN criteria, C. robusta can be assessed as VU B1ab(ii,iii)+2ab(ii,iii).

\section{Notes}

Kükenthal (1939) also listed the specimen Humbert 3344 when creating the combination under C. pantopoda. We here exclude this specimen collected at Pic d'Ivohibe Reserve in the Fianarantsoa region from $C$. robusta and place it in C. baronii. Kükenthal (1939) listed specimen Perrier de la Bâthie 16398 under C. pantopoda var. baronii. Although this specimen could not be found in the $\mathrm{P}$ herbarium, it is very likely to be $C$. robusta as it is from the same locality as the other positively identified specimens of $C$. robusta by the same collector at the same time.

Costularia laxa var. macrantha looks very similar to $C$. robusta but has paler glumes. Since its type specimen was collected at a somewhat lower elevation than the specimens identified as C. robusta, this is unsurprising since glume colour in tropical Cyperaceae often darkens with elevation in the same species (I. Larridon, pers. observ.). Kükenthal (1939) discusses the presence of a caudex in C. robusta. Although this is not clearly visible in the specimens he cited, the type specimen of $C$. laxa var. macrantha clearly has a well developed and long caudex. We here consider $C$. laxa var. macrantha to be a synonym of $C$. robusta. Kükenthal (1939) did realise a potential relationship between $C$. laxa var. macrantha and $C$. pantopoda as he included a comment under C. laxa var. macrantha to the effect of "Much deviating from the typical form of $C$. laxa and approaching C. pantopoda in appearance, but the glumes have the colour of $C$. laxa (purple and pale green) and the perianth bristles are more ciliate than plumose. Possibly, a hybrid between C. laxa and C. pantopoda." Kükenthal (1939) listed a second specimen under C. laxa var. macrantha: H. Humbert 6358 (not seen) collected in Beampingaratra, Toliara province. We here exclude this specimen from C. robusta.

15. Costularia xipholepis (Baker) Henriette \& Senterre, Phytotaxa 231: 34 (2015). 三 Cladium xipholepis Baker, Fl. Mauritius: 424 (1877). ESchoenus xipholepis (Baker) Summerh., Bull. Misc. Inform. Kew 1928: 394 (1928), p.p. quoad holotypus sed excl. Horne 626-Fig. 20 Type. Seychelles, Wright s.n. (holotype K!).

Adapted from Henriette et al. (2015): Perennial herb up to $2.5 \mathrm{~m}$ tall, caespitose, forming dense clumps. Culm c. $80 \mathrm{~cm} \times 3.5-5 \mathrm{~mm}$, cylindrical, robust. Basal leaves distichously arranged, densely set, numerous; dead leaves persistent, the older ones abscising above the leaf sheath; green leaves 7-12 on each side, arcuate; leaf-sheath 4-6 $62.9-4 \mathrm{~cm}$, semi-cylindrical, 
thick, yellowish, margins dark red, ciliate distally; leaf blade $75-123 \mathrm{~cm} \times 7-10 \mathrm{~mm}$, not pseudopetiolate, linear, gradually tapering towards apex, upwardly concave in section, coriaceous, glabrous, smooth, mid-green, margin entire, with tiny ascendant prickles, apex acute, slightly rounded, not apiculate, midrib not distinct, longitudinally striate. Cauline leaves 3-5; leaf-sheath $4.5-5.2 \times 1.2-1.5 \mathrm{~cm}$, closed, dark red at base, yellowish distally; leaf-blade shorter than in basal leaves, decreasing in length towards the apex of the culm, 40-74 cm $\times 8-10 \mathrm{~mm}$. Inflorescence 55-140 cm, narrow (7-15 cm wide), with 4-5 orders of branching; inflorescence bracts $9-14$, up to $17-27 \mathrm{~cm}$ long at basal nodes, $2.5-3.0 \mathrm{~cm}$ long at distal nodes. Peduncles unequal (longer in basal fertile nodes), 15-360 mm long, 1-7 per node, erect, compressed, slender, smooth. Pedicels of the spikelets 7.5-8.0 mm long, straight. Spikelets densely clustered, 7-8 × 1.0-1.2 mm, lanceolate, reddish-brown; rachilla persistent, straight. Glumes 7-9, distichous, completely enclosing the rachilla at base, deciduous, lanceolate, smooth, reddishbrown on the sides and towards apex, margins glabrous, apices with a straight awn (longer in basal glume), midrib distinct; basal empty glumes 5-7, the lowest glume $2.5-3.7 \times 1.0-1.5 \mathrm{~mm}$, subsequent glumes 3.3-6.8 × 1.4-2.0 mm; lower fertile glume 6.0-6.5 mm long, slightly shorter than the last empty glume; upper fertile glume 6.1-6.5 $\mathrm{mm}$ long, enclosed in the previous glume. Flowers 2, lower male, upper bisexual. Perianth bristles 6, well developed, 5.5-7.3 mm long, 23 times longer than the nutlet (beak included), sparsely plumose. Stamens 3, 5.0-7.6 mm long, not protruding or slightly protruding; anthers oblong, 1.7-4.2 mm long, yellow. Style trifid, 7.5$10.3 \mathrm{~mm}$ long (including stigmas). Nutlet stalked at maturity, trigonous, wingless, obovoid, 2 mm long (excluding beak), 0.8-0.9 mm diam., golden brown, beak with a constriction at the junction with the nutlet, $1.5 \mathrm{~mm}$ long, long-acute, $0.4 \mathrm{~mm}$ wide at base, ciliate.

\section{Distribution}

Based on Henriette et al. (2015), Costularia xipholepis is endemic to the Seychelles and restricted to Mahé and has been found in three locations all situated in the Morne Seychellois National Park: Congo Rouge (B. Senterre \& T. Stévart, observation record, 20 July 2014, $4.6512^{\circ} \mathrm{S}, 55.44126^{\circ} \mathrm{E}, 610 \mathrm{~m}$ ), Copolia and Pérard (Fig. 20). Two additional locations were recently discovered at Mont Sébert and at Glacis Sarcelles (B. Senterre, pers. comm.) (Fig. 20).

\section{Ecology}

This species is restricted to the herbaceous fringe of lower montane inselbergs (Henriette et al., 2015). It has been observed from 500 to $821 \mathrm{~m}$ but was more abundant on the site at the higher elevation, which corresponds to an altitudinal belt named the tree fern lower montane belt (Senterre, 2011; Senterre \& Wagner, 2014; Senterre et al., 2009; Henriette et al., 2015). At Copolia, it has a patchier distribution, growing on rock crevices and along fissures where the soil is damp. In all sites, it grows in association with the species previously known as Costularia hornei (basionym Schoenus hornei, nom. cons. prop.; Larridon et al., 2017b); which is now placed in the new genus Xyroschoenus (Larridon et al., 2018a). Since the exclusion of 
Xyroschoenus hornei from Costularia, only one species of Costularia is known to occur on the Seychelles.

\section{Phenology}

Flowering/fruiting specimens were collected between March to December.

\section{Conservation status}

Following Henriette et al. (2015), Costularia xipholepis is rare and highly localised. Three subpopulations representing three locations, 1.4 to $2.4 \mathrm{~km}$ apart, separated from each other by unsuitable habitat (i.e. wet forests) are within the Morne Seychellois National Park and appear healthy, with limited risks from invasive species. The AOO for the Congo Rouge population is $10 \mathrm{~m}^{2}$, Copolia $6,000 \mathrm{~m}^{2}$, and Pérard 20,000 $\mathrm{m}^{2}$ (Henriette et al., 2015). The two newly discovered sub-populations, at Mont Sébert and at Glacis Sarcelles are not well known, but the Mont Sébert one is about the same size as the one of Congo Rouge (small), while the Glacis Sarcelles population is comparable to the Copolia one (Senterre, pers. comm.) resulting in an estimated AOO totalling approx. $0.032 \mathrm{~km}^{2}$. Its EOO was estimated at approximately $5.9 \mathrm{~km}^{2}$ (Bachman et al., 2011). Both AOO and EOO fall within the limits of Critically Endangered status under criterion B. According to Henriette et al. (2015) and based on IUCN (2012) criterion $\mathrm{B}$, with an EOO $<5000 \mathrm{~km}^{2}$, AOO $<500 \mathrm{~km}^{2}$, number of locations $\leq 5$, and a projected decline of the quality of the habitat as a result of climate change, this species can be classified as Endangered EN B1ab(iii)+2ab(iii).

\section{Notes}

Henriette et al. (2015) noted that among the known species of Costularia s.s. only one presents some similarity with Costularia xipholepis, i.e. Costularia baronii from Madagascar, as both species have long leaves and hypogynous bristles much longer than the nutlet with relatively few empty glumes. However, our molecular phylogenetic results point at a sister relationship with $C$. melleri. The sister pair C. melleri (Madagascar) and C. xipholepis (Seychelles) in turn are sister to a clade encompassing the species $C$. humbertii (Madagascar) and C. cadetii (La Réunion).

\section{Conclusions}

The genus Costularia is redelimited to represent a monophyletic entity including 15 species. Although the species diversity is largely found in Madagascar, our results indicate that the genus dispersed once to Africa (Malawi, Mozambique, South Africa, Swaziland, Zimbabwe), twice to the Mascarenes (La Réunion, Mauritius), and once to the Seychelles (Mahé). Three-quarters of the species are threatened with extinction, because of restricted distribution ranges and human impact. A full taxonomic treatment is provided, including an identification key to all species, formal descriptions of two new species from Madagascar (C. andringitrensis and C. itremoensis) and one new species from La Réunion ( $C$. cadetii), and two taxa previously recognised as varieties of $C$. pantopoda are here recognised at species level (C. baronii and C. robusta). 


\section{Acknowledgements}

We thank the curators of the BR, G, GENT, K, L, MAU, P, TAN, and UPOS herbaria for the loan of specimens, imaging of specimens, and/or permission to carry out destructive sampling. We thank Pieter Asselman and Viki Vandomme for their help with the molecular lab work at Ghent University. The ANGAP Madagascar National Parks authority, the general secretariat of the AETFAT congress 2010 and the staff of the MBG office in Antananarivo are acknowledged for their help in securing collecting permits $\left(\mathrm{N}^{\circ} 082 / 10 / \mathrm{MEF} / \mathrm{SG} / \mathrm{DGF} / \mathrm{DCB} . \mathrm{SAP} / \mathrm{SLRSE}\right.$ - Isabel Larridon) for Cyperaceae in Madagascar and their help organising the expedition. We thank Vonona Randrianasolo (Kew Madagascar Conservation Centre), and Franck Rakotonasolo and Jacqueline Razanatsoa (Herbier du Parc Botanique et Zoologique de Tsimbazaza) for aiding with fieldwork. Thank you to Modesto Luceño and his student José Ignacio Márquez-Corro for collecting additional material of the new species from La Réunion for this study. Jeremy Bruhl, Wim Huygh and Modesto Luceño are acknowledged for providing photos of Costularia species. Special thanks to Juliet Beentje and Jane Browning for making line drawings of many of the species.

\section{References}

Bachman S, Moat J, Hill AW, de la Torre J, Scott B. 2011. Supporting Red List threat assessments with GeoCAT: geospatial conservation assessment tool, in: Smith, V., Penev, L. (Eds.), e-Infrastructures for data publishing in biodiversity science. ZooKeys 150:117-126 DOI 10.3897/zookeys.150.2109.

Bauters K, Meganck K, Goetghebeur P, Larridon I. 2018. Molecular phylogenetic study of Scleria subgenus Hypoporum (Sclerieae, Cyperoideae, Cyperaceae) reveals several new species to science. PLOS ONE 13(9): e0203478 DOI 10.1371/journal.pone.0203478.

Bauters K, Larridon I, Goetghebeur P. Accepted. A taxonomic study of Scleria subgenus Hypoporum: synonymy, typification and a new species-level identification key. Phytotaxa.

Browning J, Gordon-Gray KD. 1995. Studies in Cyperaceae in southern Africa 26: Glume epidermal silica deposits as a character in generic delimitation of Costularia and Cyathocoma as distinct from Tetraria and other allies. South African Journal of Botany 61:66-71 DOI 10.1016/S0254-6299(15)30481-6.

Browning J, Gordon-Gray KD. 1996. Studies in Cyperaceae in southern Africa 29: Costularia natalensis, an endangered species. South African Journal of Botany 62:155-159 DOI 10.1016/S0254-6299(15)30616-5.

Browning J, Gordon-Gray KD. 1999. Studies in Cyperaceae in southern Africa 33: a new monotypic genus, Capeobolus. South African Journal of Botany 65:218-222 DOI 10.1016/S0254-6299(15)30977-7.

Bruhl JJ. 1995. Sedge genera of the world: relationships and a new classification of the Cyperaceae. Australian Systematic Botany 8:125-305 DOI 10.1071/SB9950125. 
Burtt, B.L. 1988. Cyperaceae. In: O.M. Hilliard \& B.L. Burtt (eds), Notes on some plants of southern Africa chiefly from Natal 14. Notes of the Royal Botanic Garden Edinburgh 45:77-78.

Catalogue des herbiers de Genève. 2018. Conservatoire \& Jardin botaniques de la Ville de Genève. http://www.ville-ge.ch/musinfo/bd/cjb/chg/ accessed 30.10.2018.

Chermezon H. 1937. Cypéracées. In: H. Humbert (ed.), Flore de Madagascar 29: 1-335. Imprimerie officièle, Tananarive.

Clarke CB. 1894. Cyperaceae. In: T. Durand \& H. Schinz (eds), Conspectus Florae Africae 5: 526-692. Jardin Botanique de l'Etat, Bruxelles.

Clarke CB. 1897-1898. Cyperaceae. In: W.T. Thiselton-Dyer (ed.), Flora Capensis 7: 149-310. Reeve, London.

Faranirina L. 2017. Costularia melleri. The IUCN Red List of Threatened Species 2017: e.T88508987A88509022. DOI 10.2305/IUCN.UK.20172.RLTS.T88508987A88509022.en.

Galán Díaz J, Bauters K, Rabarivola L, Xanthos M, Goetghebeur P, Larridon I. SubmittedAccepted. A revision of Scleria (Cyperaceae) in Madagascar. Blumea.

Goetghebeur P. 1986. Genera Cyperacearum. Een bijdrage tot de kennis van de morfologie, systematiek en fylogenese van de Cyperaceae-genera. Unpublished D. Phil. Thesis, Ghent University, Belgium.

Govaerts R, Simpson DA, Goetghebeur P, Wilson KL, Egorova T, Bruhl J. 2018. World checklist of Selected Plant Families. Cyperaceae. The Board of Trustees of the Royal Botanic Gardens, Kew. Published on the Internet; http://www.kew.org/wcsp/monocots/ accessed 01.06.2018.

Henriette E, Larridon I, Morel C, Goetghebeur P, Senterre B. 2015. Revision of the genus Costularia (Cyperaceae: Schoeneae) for the flora of the Seychelles, including the rediscovery and resurrection of a rare endemic species. Phytotaxa 231:31-41 DOI 10.11646/phytotaxa.231.1.3.

HerbCat. 2018. The Herbarium Catalogue, Royal Botanic Gardens, Kew. Published on the Internet http://www.kew.org/herbcat/ accessed 30.10.2018.

IUCN. 2012. IUCN red list categories and criteria: version 3.1, vol 4, 2nd edn. IUCN, Gland, Switserland.

IUCN Standards and Petitions Subcommittee. 2014. Guidelines for Using the IUCN Red List Categories and Criteria. Version 11. Prepared by the Standards and Petitions Subcommittee. Downloadable from http://www.iucnredlist.org/documents/RedListGuidelines.pdf.

IUCN. 2018. The IUCN Red List of Threatened Species. Version 2018-2. http://www.iucnredlist.org/ accessed 14.11.2018.

Katoh K, Asimenos G, Toh H. 2009. Multiple alignment of DNA sequences with MAFFT. Methods in Molecular Biology 537:39-64 DOI 10.1007/978-1-59745-251-9_3. 
Katoh K, Standley DM. 2013. MAFFT multiple sequence alignment software version 7: improvements in performance and usability. Molecular Biology and Evolution 30:772780 DOI 10.1093/molbev/mst010.

Kearse M, Moir R, Wilson A, Stones-Haves S, Cheung M, Sturrock S, Buxton S, Cooper A, Markowitz S, Duran C, Thierer T, Ashton B, Meintjes P, Drummond A. 2012. Geneious Basic: an integrated and extendable desktop software platform for the organization and analysis of sequence data. Bioinformatics 28:1647-1649 DOI 10.1093/bioinformatics/bts199.

Kükenthal G. 1939. Vorarbeiten zu einer Monographie der Rhynchosporoideae 5. Repertorium Specierum Novarum Regni Vegetabilis 46:65-76

Lanfear R, Calcott B, Ho SYW, Guindon S. 2012. PartitionFinder: combined selection of partitioning schemes and substitution models for phylogenetic analyses. Molecular Biology and Evolution 29:1695-1701 DOI 10.1093/molbev/mss020.

Larridon I, Verboom GA, Muasya AM. 2017a. (2555) Proposal to conserve the name Tetraria (Cyperaceae) with a conserved type. Taxon 66: 1226-1227 DOI 10.12705/665.22.

Larridon I, Govaerts R, Goetghebeur P. 2017b. (2554) Proposal to conserve the name Schoenus hornei (Cyperaceae) with a conserved type. Taxon 66: 1225-1226 DOI 10.12705/665.21.

Larridon I, Semmouri I, Bauters K, Viljoen JA, Prychid CJ, Muasya AM, Bruhl JJ, Wilson KA, Goetghebeur P. 2018a. Molecular phylogenetics of the genus Costularia (Schoeneae, Cyperaceae) reveals multiple distinct evolutionary lineages. Molecular Phylogenetics and Evolution 126:196-209 DOI 10.1016/j.ympev.2018.04.016.

Larridon I, Verboom GA, Muasya AM. 2018b. Revised delimitation of the genus Tetraria (Cyperaceae, tribe Schoeneae, Tricostularia clade). South African Journal of Botany 118: 18-22. DOI 10.1016/j.sajb.2018.06.007.

Miller MA, Pfeiffer W, Schwartz T. 2011. The CIPRES science gateway: a community resource for phylogenetic analyses. Proceedings of the 2011 TeraGrid Conference: Extreme Digital Discovery: 41. ACM, New York DOI 10.1145/2016741.2016785.

Moat J, Smith P. 2012. Atlas of the Vegetation of Madagascar. Royal Botanic Gardens, Kew.

Müller J, Müller K, Neinhuis C, Quandt D. 2010. PhyDEPhylogenetic Data Editor, version 0.9971. Available at http://www.phyde.de/ (accessed on 10 January 2016).

Muséum national d'Histoire naturelle. 2018. Vascular plants (P). https://science.mnhn.fr/institution/mnhn/collection/p/item/search accessed 30.10.2018.

Rambaut A, Drummond AJ. 2007. Tracer, a MCMC Trace Analysis Tool. Institute of Evolutionary Biology, University of Edinburgh. http://beast.bio.ed.ac.uk/.

Ronquist F, Teslenko M, van der Mark P, Ayres DL, Darling A, Hohna S, Larget B, Liu L, Suchard MA, Huelsenbeck JP. 2012. MrBayes 3.2: Efficient Bayesian phylogenetic inference and model choice across a large model space. Systematic Biology 61:539-542 DOI 10.1093/sysbio/sys029. 
Seberg O. 1986. Schoenoides, a new genus of Cyperaceae from Tasmania. Willdenowia 16:181$186 \mathrm{http://www.jstor.org/stable/3996315.}$

Seberg O. 1988a. Leaf anatomy of Oreobolus R.Br. and Schoenoides Seberg. Botanische Jahrbücher fur Systematik, Pflanzengeschichte und Pflanzengeographie 110:187-214.

Seberg O. 1988b. Taxonomy, phylogeny, and biogeography of the genus Oreobolus R. Br. (Cyperaceae), with comments on the biogeography of South Pacific continents. Botanical Journal of the Linnean Society 96:119-195 DOI 10.1111/j.1095-8339.1988.tb00632.x.

Semmouri I, Bauters K, Léveillé-Bourret E, Starr JR, Goetghebeur P, Larridon I. 2018. The phylogeny and systematics of Cyperaceae, the evolution and importance of embryo morphology. Botanical Review DOI 10.1007/s12229-018-9202-0.

Senterre B. 2011. On the forest types of the Seychelles. Kapisen 12:5-7.

Senterre B, Gerlach J, Mougal J, Matatiken DE. 2009. Old growth mature forest types and their floristic composition along the altitudinal gradient on Silhouette Island (Seychelles) - the telescoping effect on a continental mid-oceanic island. Phytocoenologia 39:157-174 DOI 10.1127/0340-269X/2009/0039-0157.

Senterre B, Wagner M. 2014. Mapping Seychelles habitat-types on Mahé, Praslin, Silhouette, La Digue and Curieuse. Consultancy Report. Government of Seychelles, United Nations Development Programme, Victoria, Seychelles, 119 pp.

Shorthouse, David P. 2010. SimpleMappr, an online tool to produce publication-quality point maps. Available at http://www.simplemappr.net (accessed 29 October 2018).

Stamatakis A. 2014. RAxML Version 8: a tool for phylogenetic analysis and post-analysis of large phylogenies. Bioinformatics 30:1312-1313 DOI 10.1093/bioinformatics/btu033.

Stöver BC, Müller KF. 2010. TreeGraph 2: combining and visualizing evidence from different phylogenetic analyses. BMC Bioinformatics 11:7 DOI 10.1186/1471-2105-11-7.

Thiers B, continuously updated. Index herbariorum. Available at http://sweetgum.nybg.org/science/ih/ (accessed on 20 November 2018).

Turland NJ, Wiersema JH, Barrie FR, Greuter W, Hawksworth DL, Herendeen PS, Kusber W-H, Li De-Zhu, Marhold K, May TW, McNeill J, Monro AM, Prado J, Price MJ, Smith GF. 2018. International Code of Nomenclature for algae, fungi, and plants (Shenzhen Code) adopted by the Nineteenth International Botanical Congress Shenzhen, China, July 2017. Koeltz Botanical Books.

Verboom GA. 2006. A phylogeny of the schoenoid sedges (Cyperaceae: Schoeneae) based on plastid DNA sequences, with special reference to the genera found in Africa. Molecular Phylogenetics and Evolution 38:79-89 DOI 10.1016/j.ympev.2005.05.012.

Viljoen J-A, Muasya AM, Barrett RL, Bruhl JJ, Gibbs AK, Slingsby JA, Wilson KL, Verboom GA. 2013. Radiations and repeated transoceanic dispersal of Schoeneae (Cyperaceae) through the southern hemisphere. American Journal of Botany 100:24942508 DOI 10.3732/ajb.1300105.

Vrijdaghs A, Reynders M, Larridon I, Muasya AM, Smets E, Goetghebeur P. 2010.

Spikelet structure and development in Cyperoideae (Cyperaceae): a monopodial general 
model based on ontogenetic evidence. Annals of Botany 105:555-571 DOI

1428 Vrijdaghs A, Reynders M, Muasya AM, Larridon I, Goetghebeur P, Smets E. 2011. Morphology and development of spikelets and flowers in Cyperus and Pycreus (Cyperaceae). Plant Ecology and Evolution 144:44-63 DOI 10.5091/plecevo.2011.436.

Zhang X, Marchant A, Wilson KL, Bruhl JJ. 2004. Phylogenetic relationships of Carpha and its relatives (Schoeneae, Cyperaceae) inferred from chloroplast trnL intron and trnL-trnF intergenic spacer sequences. Molecular Phylogenetics and Evolution 31:647-657 DOI 10.1016/j.ympev.2003.09.004. 